\title{
Bibliography of urban history 2021
}

\author{
Andrew McTominey
}

The present bibliography is a continuation of and a complement to those published in the Urban History Yearbook 1974-91 and Urban History from 1992. The arrangement and format closely follows that of previous years. The list of abbreviations identifies only those periodicals from which articles cited this year have been taken, though many other journals are also checked.

\section{General}

Research methods, aids and materials

Maps and plans

Archives - descriptions and examples

Urban history, definitions and aims

Historiography

Empirical studies of urbanization

History, growth and fortunes of individual towns

Literary portrayals and personal reminiscences

\section{Population}

General features of urban population

Natality and mortality

Disease

Medicine

Migration to, from and between towns

Family and household structure

\section{Physical structure}

Research methods, aids and materials

Physical and structural characteristics of towns

Physical and structural characteristics of areas

Architecture

Housing

Social life

Heritage and the historic environment

\section{Social structure}

Research methods, aids and materials

Social organization, clubs and societies

Class structure

Social life

Social life, customs and traditions

Religion

Recreation

Social problems and deviance

() The Author(s), 2021. Published by Cambridge University Press. 
Social reforms and improvement

Minority groups

Family life

Gender

Sexualities

\section{Economic activity}

Urban economic activity

Industry

Food supply

Finance, banking and industry

Consumption

Working conditions

Labour organization

\section{Communications}

Inter-urban communications

\section{Politics and administration}

Aspects of urban administration

Political activism

\section{Shaping the urban environment}

Town planning (and environmental control)

Urban renewal

\section{Urban culture}

Urban renewal

Urban culture and entertainment

Exchange of information

Education

Emotions and the senses

\section{Attitudes towards cities}

Attitudes towards cities

Views of the city in literature, graphics and drama

\section{Journals abbreviations used}
A Antiquity
$A \& R$ Archives \& Records
AAAG Annals of the American Association of Geographers
ADH Annales de démographie historique
ANH Archives of Natural History
Arc Archives
ArchH Architectural History
$B$ \& $L \quad$ Buildings and Landscapes
BatW Britain and the World
BHM Bulletin of the History of Medicine
BJHS British Journal for the History of Science
BOEC Book of the Old Edinburgh Club 
BQ Baptist Quarterly

$\mathrm{BuH} \quad$ Business History

$\mathrm{CBH} \quad$ Contemporary British History

$\mathrm{CBMH}$ Canadian Bulletin of Medical History

$\mathrm{ChH}$ Church History

ChP Childhood in the Past

CitC City and Community

ContC Continuity and Change

CSSH Comparative Studies in Society and History

CulSH Cultural and Social History

EAmS Early American Studies

EcHR Economic History Review

Emus Early Music

EMW Early Modern Women

EnH Environmental History

EnvH Environment and History

EPB Environment and Planning $B$

EPC Environment and Planning $C$

EPD Environment and Planning D

ERC Explorations in Renaissance Culture

ES Enterprise and Society

EurRH European Review of History

$\mathrm{FCH} \quad$ Family and Community History

FH French History

FHS French Historical Studies

$G \& H \quad$ Gender and History

GE Global Environment

$\mathrm{GeH} \quad$ German History

GFH Global Food History

H History

HA History Australia

HC History Compass

HE History of Education

HF History of the Family

Hire History Ireland

HJ Historical Journal

HM Historical Methods

HR Historical Research

HRC History of Retailing and Consumption

HT History Today

HU Histoire urbaine

HWJ History Workshop Journal

$I$ \& $M \quad$ Immigrants \& Minorities

IAR Industrial Archaeology Review

IESH Irish Economic and Social History

IESHR Indian Economic and Social History Review

IHS Irish Historical Studies

IJHA International Journal of Historical Archaeology

IJHerS International Journal of Heritage Studies

IJHS International Journal of the History of Sport

IJMH International Journal of Maritime History

IJRLH International Journal of Regional and Local History

ILWCH International Labor and Working-Class History

IM Imago Mundi

IRSH International Review of Social History 


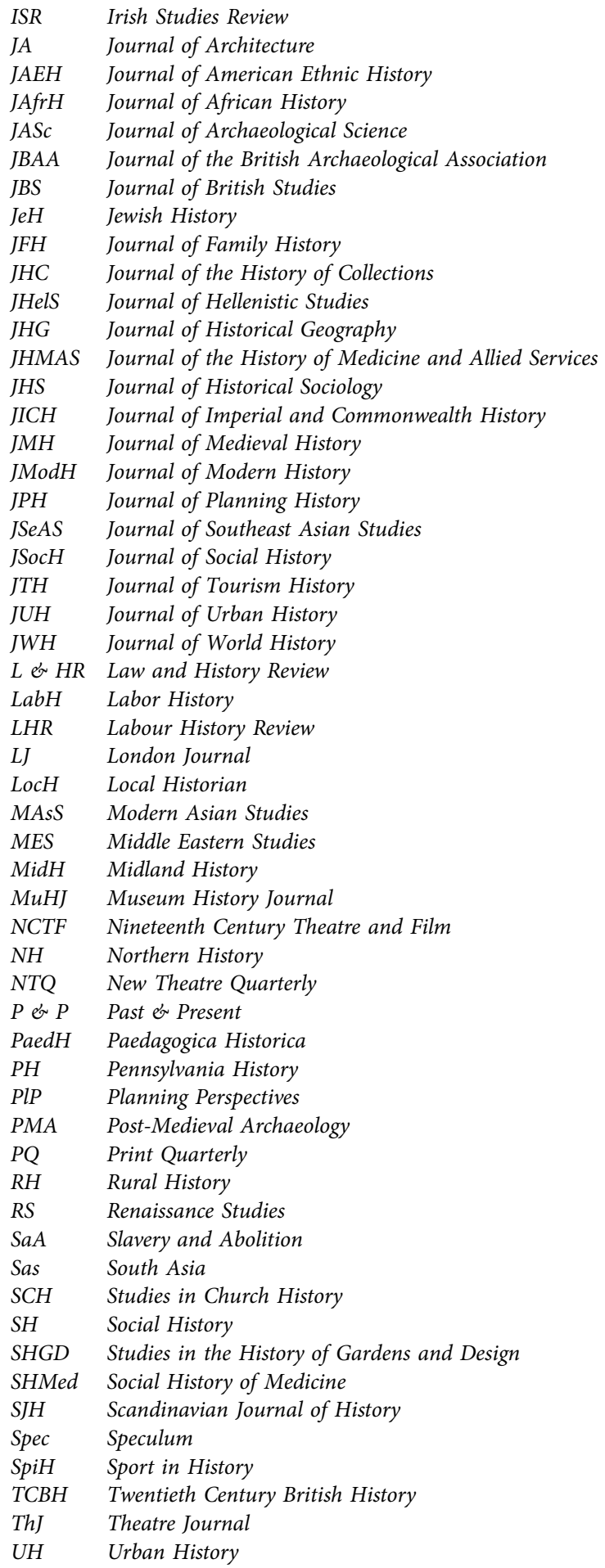


US Urban Studies

VA Vernacular Architecture

VCB Visual Culture in Britain

VPR Victorian Periodicals Review

WH Water History

WomHR Women's History Review

YAJ Yorkshire Archaeological Journal

\section{General}

\section{Research methods, aids and materials}

1 BOEHM L K, Reframing, rethinking, and remembering: considering the Digital Harrisburg Project. $P H$ 871 (2020) 233-42.

2 CLAXTON W, HARVEY M \& ROLLASON L, The rites of Durham. Woodbridge: Boydell \& Brewer 2020. pp 825.

3 RAMOS S J, COVID-19 and planning history: a spacing oddity. PlP 354 (2020) 579-81.

\section{Maps and plans}

4 PLATT S E, Urban dialectics, misrememberings, and memory-work: the Halsey map of Charleston, South Carolina. IJHA 244 (2020) 989-1014.

\section{Archives - descriptions and examples}

5 BAKER P, Securing the British Records Association's legacy: cataloguing the Association's archives at the London Metropolitan Archives. Arc 551 (2020) 39-47.

6 BARBOT M \& CARVAIS R, Des archives pour analyser la ville et pour dessiner ses territoires. Les procès-verbaux d'expertise parisienne des greffiers des bâtiments. HU 591 (2020) 63-84.

7 BEAUVIEUX F, Constitution, conservation et reconstitution d'archives urbaines en temps de catastrophe. Le réseau d'urgence d'hôpitaux de Marseille pendant la peste de 1720-1722. HU 591 (2020) 157-77.

8 BOURILLON F \& COUDROY DE LILLE L, Archives urbaines, introduction. HU 591 (2020) 37-41.

9 CHABOD A, Au cœur de l'espace public. Le dépôt athénien du Metrôon comme symbole du gouvernement démocratique. HU 591 (2020) 43-62.

10 CUVELIER L, L'affiche d'avant l'affiche. Biographies d'une archive urbaine. HU 591 (2020) 85-103.

11 D'EMILIO J, Queer legacies: stories from Chicago's LGBTQ archives. Chicago: University of Chicago Press 2020. pp 208.

12 DENMAT-LEON A, Constituer des archives urbaines à Nantes à la fin du Moyen Âge. La guerre franco-bretonne, point de départ d'une mise en registres et en coffres de la memoria de la ville? $H U 59$ 1 (2020) $125-38$.

13 FRIOUX S, Documenter la transition environnementale urbaine: sources, méthodes, valorisation. Le cas de l'agglomération lyonnaise. HU 591 (2020) 179-99.

14 LESCUYER C, Les projets-types de logements économiques et familiaux homologués par le MRU. Constitution, usages et limites d'archives urbaines. HU 591 (2020) 105-24.

15 LUTZ C A, MAHARJAN R \& CRAWFORD S, Going against the archival grain: case studies of pop culture archives of a music scene, regional zines, and local beer. $A \& R 413$ (2020) 254-73.

16 RECASENS M, Archiver la mémoire. Les consuls toulousains face aux événements de mai 1562 . HU $591(2020)$ 139-56. 
17 SELLERS R M \& HEWITT S, Carlisle Museum's Natural History Record Bureau, 1902-1912: Britain's first local environmental records centre. ANH 471 (2020) 1-15.

\section{Urban history, definitions and aims}

18 GRIFFITHS S \& VAUGHAN L, Mapping spatial cultures: contributions of space syntax to research in the urban history of the nineteenth-century city. UH 473 (2020) 488-511.

19 GUNN S, Heterodoxies: new approaches to power and agency in the modern city. In GUNN S \& HULME T eds, New approaches to governance and rule in urban Europe since 1500. Abingdon: Routledge 2020. 253-75.

20 JACKSON K C, Understanding the urban landscape. LocH 503 (2020) 196-214.

21 LAWHON M, Making urban theory: learning and unlearning through southern cities. Abingdon: Routledge 2020. pp 136.

22 NOBLE M, Finding Edinburgh's pasts: introducing the OEC bibliography of Edinburgh history. BOEC 161 (2021) 103-8.

23 PAUL J, Jean Aubin's article 'Elements for the study of urban agglomerations in medieval Iran' in context. In DURAND-GUÉDY D, MOTTAHEDEH R \& PAUL J eds, Cities of medieval Iran. Leiden: Brill 2020. 21-38.

24 RODGER R \& RAU S, Thinking spatially: new horizons for urban history. UH 473 (2020) 372-83.

\section{Historiography}

25 BALTO S, White rage, white liberals, and the making of the Second Ghetto. JUH 463 (2020) 511-15.

26 CONNOLLY N D B, The southern side of Chicago: Arnold R. Hirsch and the renewal of southern urban history. JUH 463 (2020) 505-10.

27 FERNANDEZ L, In the shadow of the Second Ghetto. JUH 463 (2020) 500-4.

28 GILFOYLE T J, Introduction: urban history, Arnold Hirsch, and the second ghetto thesis redux. JUH 463 (2020) 471-7.

29 GRASER H, HÄBERLEIN M \& TLUSTY B A, Sources and historiography. In TLUSTY B A \& HÄBERLEIN M eds, A companion to late medieval and early modern Augsburg. Leiden: Brill 2020. 3-19.

30 HOCHADEL O, Periphery and metropolis: some historiographic reflections on the urban history of science. In ASH M G ed, Science in the metropolis: Vienna in transnational context, 1848-1918. Abingdon: Routledge 2020. 41-62.

31 JENKINS D, Money and the ghetto, money in the ghetto. JUH 463 (2020) 494-9.

32 PAUL J, Cities in medieval Iran: a review of recent publications. In DURAND-GUÉDY D, MOTTAHEDEH R \& PAUL J eds, Cities of medieval Iran. Leiden: Brill 2020. 5-20.

33 ROHMANN G, Textual representation: chronicles. In TLUSTY B A \& HÄBERLEIN M eds, A companion to late medieval and early modern Augsburg. Leiden: Brill 2020. 69-98.

34 TAYLOR K-Y, The banality of segregation: why Hirsch still helps us understand our racial geography. JUH 463 (2020) 490-3.

\section{Empirical studies of urbanization}

35 LAM T, Urbanism of fear: a tale of two Chinese Cold War cities. In BROOK R, DODGE M \& HOGG J eds, Cold War cities: politics, culture and atomic urbanism, 1945-1965. Abingdon: Routledge 2020. $108-15$. 
36 MADSEN J M, From trophy towns to city-states: urban civilization and cultural identities in Roman Pontus. Philadelphia: University of Pennsylvania Press 2020. pp 280.

37 MÄRZ O, An urban-rural continuum? A spatial comparison in mid-eighteenth-century northern Germany. UH 473 (2020) 421-47.

38 SAHOO D, Urbanization in India during the British period (1857-1947). Abingdon: Routledge 2020. pp 330.

39 WAKEMAN R, A modern history of European cities: 1815 to the present. London: Bloomsbury Academic 2020. pp 392.

40 WOOLF G, The life and death of ancient cities. Oxford: Oxford University Press 2020. pp 528.

\section{History, growth and fortunes of individual towns}

This section is arranged alphabetically by the name of the town

41 GUSIC I, Contesting peace in the postwar city: Belfast, Mitrovica and Mostar. London: Palgrave Macmillan 2020. pp xx +298.

42 BARTON M, Before the city was beautiful. PH 871 (2020) 92-6.

43 DURAND-GUÉDY D, Isfahan during the Turko-Mongol period (11th-15th centuries). In DURAND-GUÉDY D, MOTTAHEDEH R \& PAUL J eds, Cities of medieval Iran. Leiden: Brill 2020. 253-312.

44 TANISS F \& HEIN C, Space, representation, and practice in the formation of Izmir during the long nineteenth century. In REIMANN C \& ÖHMANN M eds, Migrants and the making of the urban-maritime world: agency and mobility in port cities, c. 1570-1940. Abingdon: Routledge 2020. 43-61.

45 AMANAT M \& MOTTAHEDEH R P, Medieval Kashan: crossroads of commerce and culture. In DURAND-GUÉDY D, MOTTAHEDEH R \& PAUL J eds, Cities of medieval Iran. Leiden: Brill 2020. 395-429.

46 IVKOVSKA V, An Ottoman era town in the Balkans: the case study of Kavala. Abingdon: Routledge 2020. pp 226.

47 LATHAM-SPRINKLE J, A lost city in the North Caucasus. HT 7011 (2020) 22-4.

48 LUENGO P, Manila, 1645. Abingdon: Routledge 2020. pp 170.

49 GUSIC I, Contesting peace in the postwar city: Belfast, Mitrovica and Mostar. London: Palgrave Macmillan 2020. pp xx +298 .

50 GUSIC I, Contesting peace in the postwar city: Belfast, Mitrovica and Mostar. London: Palgrave Macmillan 2020. pp xx +298 .

51 ESE A \& ESE K, The city makers of Nairobi: an African urban history. Abingdon: Routledge 2020. pp 216.

52 BULLIET R W, Why Nishapur? In DURAND-GUÉDY D, MOTTAHEDEH R \& PAUL J eds, Cities of medieval Iran. Leiden: Brill 2020. 100-23.

53 SCHJERNING C, An ancient and industrious place: visual geographies and urban identity in a Danish provincial town, c. 1780-1915. UH 471 (2020) 63-85.

54 PIASECKA M, Early modern Oels and the singularities of local history. GeH 382 (2020) 211-39.

55 WEST-HARLING V, Rome, Ravenna, and Venice, 750-1000. Oxford: Oxford University Press 2020. pp 720. 
56 LELO K, Analysing spatial relationships through the urban cadastre of nineteenth-century Rome. UH 473 (2020) 467-87.

57 WEST-HARLING V, Rome, Ravenna, and Venice, 750-1000. Oxford: Oxford University Press 2020. pp 720 .

58 DU J, The Shenzhen experiment: the story of China's instant city. Cambridge MA: Harvard University Press 2020. pp 384.

59 CARTLEDGE P, Thebes: the forgotten city. HT 706 (2020) 62-3.

60 HOJER L \& PEDERSEN M A, Urban hunters: dealing and dreaming in times of transition. New Haven: Yale University Press 2020. pp 288.

61 WEST-HARLING V, Rome, Ravenna, and Venice, 750-1000. Oxford: Oxford University Press 2020. pp 720.

62 CHOKSY J K, Yazd: a 'good and noble city' and an 'abode of worship'. In DURAND-GUÉDY D, MOTTAHEDEH R \& PAUL J eds, Cities of medieval Iran. Leiden: Brill 2020. 217-52.

63 HAN E C, Rise of a Japanese Chinatown: Yokohama, 1894-1972. Cambridge MA: Harvard University Press 2020. pp 266.

\section{Literary portrayals and personal reminiscences}

64 LAGRAND J B \& PETTEGREW D, Harrisburg's historic African American community: an interview with Calobe Jackson Jr. PH 871 (2020) 212-24.

\section{Population}

\section{General features of urban population}

65 CONNOR D S, GUTMANN M P, CUNNINGHAM A R, CLEMENT K K \& LEYK S, How entrenched is the spatial structure of inequality in cities? Evidence from the integration of census and housing data for Denver from 1940 to 2016. AAAG 1104 (2020) 1022-39.

66 PETTEGREW D \& SARVIS A, The Digital Harrisburg Project: placing the population of a progressive era city. $P H 871$ (2020) 22-44.

67 RAJKAY B, Urban topography, population, visual representations. In TLUSTY B A \& HÄBERLEIN M eds, A companion to late medieval and early modern Augsburg. Leiden: Brill 2020. 20-45.

68 RODRÍGUEZ V P, KELLNER C M, HIGELÍN R \& DE LEÓN R H P, Urban to the bone: isotopic and faunal dietary data from formative-period Cerro Jazmín, Mixteca Alta, Oaxaca, México. JASc 1211 (2020) $1-11$.

\section{Natality and mortality}

69 BOIVIN K M, Two-story charnel-house chapels and the space of death in the medieval city. In PERKINSON S \& TUREL N eds, Picturing death 1200-1600. Leiden: Brill 2020. 79-103.

70 DAVENPORT R J, Urbanization and mortality in Britain, c. 1800-50. EcHR 732 (2020) 455-85.

71 EMMERSON A L C, Life and death in the Roman suburb. Oxford: Oxford University Press 2020. pp 304 .

72 FIALOVA L, TESARKOVA K H \& KUPROVA B J, The 'high infant mortality trap': the relationship between birth intervals and infant mortality - the example of two localities in Bohemia between the 17th and 19th centuries. HF 251 (2020) 94-134. 
73 GALIANA-SÁNCHEZ, MARTÍNEZ-ZAPATA R \& BERNABEU-MESTRE J, Child care nurses and the fight against maternal and child morbidity and mortality. Valencia before the health transition. ADH 1381 (2020) 179-206.

74 LI M, Childbirth transformation and new style midwifery in Beijing, 1926-1937. HF 253 (2020) 406-31.

75 MARSHALL J, Race, death, and public health in early Philadelphia, 1750-1793. PH 872 (2020) 364-89.

76 MARTYN R, CRAIG O E, ELLINGHAM S T D, ISLAM M, FATTORE L, SPERDUTI A, BONDIOLI L \& THOMPSON T, A re-evaluation of manner of death at Roman Herculaneum following the AD 79 eruption of Vesuvius. A 94373 (2020) 76-91.

\section{Disease}

77 AGRESTA A, From purification to protection: plague response in late medieval Valencia. Spec 952 (2020) 371-95.

78 ALLMOND G, Pandemic cholera in Belfast, 1832. Hire 284 (2020) 22-5.

79 BERTOMEU-SÁNCHEZ J R, The colic of Madrid (1788-1814): experts, poisons, politics, and war at the end of the Ancien Régime in Spain. SHMed 333 (2020) 728-48.

80 CARTER S W, The 1918 influenza outbreak in Harrisburg. PH 871 (2020) 148-54.

81 CASTENBRANDT H, REVUELTA-EUGERCIOS B A \& TORÉN K, Differences in health: the influence of gender and institutional settings on sickness claims in Gothenburg, Sweden (1898-1950). SHMed 334 (2020) 1259-81.

82 ENGELMANN L, A plague of kinyounism: the caricatures of bacteriology in 1900 San Francisco. SHMed 332 (2020) 489-514.

83 FORD R, Controlling contagion? Watercress, regulation and the Hackney typhoid outbreak of 1903. RH 312 (2020) 181-94.

84 GENTILCORE D \& PRIANI E, 'San servolo lunatic!': segregation and integration in the life cycle of pellagra patients at Venice's provincial asylums (1842-1912). In CRAWSHAW J L S, LATIN I B \& VONGSATHORN K eds, Tracing hospital boundaries. Leiden: Brill 2020. 88-111.

85 GILBOY R, Crisis mortality in Civil War Oxford 1642-1646. LocH 501 (2020) 2-20.

86 GREEN D R, BROWN D H L \& MCILVENNA K, Addressing ill health: sickness and retirement in the Victorian Post Office. SHMed 332 (2020) 559-85.

87 HEIN-KIRCHER H, Best practices from a Polish perspective: improving health conditions in Lviv around 1900. In GANTNER E, HEIN-KIRCHER H \& HOCHADEL O eds, Interurban knowledge exchange in southern and eastern Europe, 1870-1950. Abingdon: Routledge 2020. 134-53.

88 KINZELBACH A, Leprosaria: the simultaneity of segregation and integration in early modern southern German towns. In CRAWSHAW J L S, LATIN I B \& VONGSATHORN K eds, Tracing hospital boundaries. Leiden: Brill 2020. 46-66.

89 PETERSON A M, Beyond the city's walls: the lepers of Narbonne and Siena before the Black Death. In CRAWSHAW J L S, LATIN I B \& VONGSATHORN K eds, Tracing hospital boundaries: integration and segregation in southeastern Europe and beyond, 1050-1970. Leiden: Brill 2020. 25-45.

90 SIENA K, On courtroom dramas and plot twists: typhus in eighteenth-century London. BHM 944 (2020) 590-601.

91 STEERE-WILLIAMS J, The filth disease: typhoid fever and the practices of epidemiology in Victorian England. Woodbridge: Boydell \& Brewer 2020. pp 340. 
92 STEIN C, Of invisible boundaries: bodies, plagues, and healers. In TLUSTY B A \& HÄBERLEIN M eds, A companion to late medieval and early modern Augsburg. Leiden: Brill 2020. 46-68.

93 TEMEL M K, The 1918 'Spanish Flu' pandemic in the Ottoman capital, Istanbul. CBMH 371 (2020) 195-231.

94 VIEYRA A \& BARAHONA A, Clinical practices: epilepsy at the National Hospital for the Paralysed and Epileptic, London, from 1860 to 1870. SHMed 334 (2020) 1167-87.

95 WIEGESHOFF A, The 'greatest traveller of them all': rats, port cities, and the plague in U.S. imperial history (c. 1899-1915). In REIMANN C \& ÖHMANN M eds, Migrants and the making of the urban-maritime world: agency and mobility in port cities, c. 1570-1940. Abingdon: Routledge 2020. $109-29$.

96 WILLIAMSON F \& PROUST K, 'Living in a state of filth and indifference to...their health': weather, public health and urban governance in colonial George Town, Penang. EnvH 263 (2020) 233-59.

\section{Medicine}

97 BAMJI A, Blowing smoke up your arse: drowning, resuscitation, and public health in eighteenthcentury Venice. BHM 941 (2020) 29-63.

98 EVANS D, Challenges and opportunities in documenting the recent history of public health: the health of Bristol after 1948. SHMed 332 (2020) 641-58.

99 GELTNER G, The path to Pistoia: urban hygiene before the Black Death. P \& $P 2461$ (2020) 3-33.

100 HÁJKOVÁ A, Medicine in Theresienstadt. SHMed 331 (2020) 79-105.

101 HELM D P, 'Physician's prescriptions accurately prepared' - the mid-nineteenth-century prescription books of four Gloucester chemists. JHMAS 753 (2020) 270-98.

102 KRALJ-BRASSARD R \& LAZAREVIĆ I, The role of segregation and integration in identity formation for foundlings in early modern Dubrovnik. In CRAWSHAW J L S, LATIN I B \& VONGSATHORN K eds, Tracing hospital boundaries. Leiden: Brill 2020. 67-87.

103 MANT M, 'A little time woud compleat the cure': broken bones and fracture experiences of the working poor in London's general hospitals during the long eighteenth century. SHMed 332 (2020) 438-62.

104 ROBISON K, Healers in the making: students, physicians, and medical education in medieval Bologna (1250-1550). Leiden: Brill 2020. pp x 199.

105 ROBISON K L, For the benefit of students: memory and anatomical learning at Bologna in the fourteenth to early sixteenth centuries. JHMAS 752 (2020) 135-50.

106 SKIPPER A, The 'dog doctors' of Edwardian London: elite canine veterinary care in the early twentieth century. SHMed 334 (2020) 1233-58.

107 WAINWRIGHT M C, Non-Catholic pilgrims and the Hospital of SS.Trinità dei Pellegrini e Convalescenti (1575-1650). In WAINWRIGHT M C \& MICHELSON E eds, A companion to religious minorities in early modern Rome. Leiden: Brill 2020. 89-113.

\section{Migration to, from and between towns}

108 ABRECHT R R, An immigrant neighbourhood in ancient Rome. UH 471 (2020) 2-22.

109 AUERBACH S, 'You have lost all that is German of you in the dock': immigrant communities and the wartime state in London, 1914-18. TCBH 314 (2020) 503-29.

110 FEYS T, From queen of seaside resorts to expulsion corridor: monitoring the entry, stay, and expulsion of foreigners in Ostend (1838-1914). JTH 123 (2020) 213-36. 
111 GIBERTI M, The city [un]divided: forms of urban organization in Naba'a District - Bourj Hammoud (Beirut). In FOLIN M \& PORFYRIOU H eds, Controversial heritage and divided memories from the nineteenth through the twentieth centuries. Abingdon: Routledge 2020. 152-68.

112 HANNOUM A, Living Tangier: migration, race, and illegality in a Moroccan city. Philadelphia: University of Pennsylvania Press 2020. pp 312.

113 IBARZ J, Labor mobility and migrations in the Barcelona docks, c. 1900-1950. In REIMANN C \& ÖHMANN M eds, Migrants and the making of the urban-maritime world: agency and mobility in port cities, c. 1570-1940. Abingdon: Routledge 2020. 251-73.

114 KOURELIS K \& PETTEGREW D, The Greek communities of Harrisburg and Lancaster: a study of immigration, residence, and mobility in the City Beautiful era. PH 871 (2020) 66-91.

115 LOIRA J P, Migration and the continuity of a city: Lluis Pons d'Icart's Libro de las grandezas de Tarragona (1572). In FOLIN M \& MUSARRA A eds, Cultures and practices of coexistence from the thirteenth through the seventeenth centuries. Abingdon: Routledge 2020. 219-36.

116 LOOCKX K, Migration trajectories of seafarers during the transition from sail to steam: change and continuity in Antwerp, 1850-1900. IJMH 323 (2020) 616-35.

117 LOOCKX K, Migration, maritime labor, and family: the life course of Carel Hendrik Bloebaum, 1848-1916. In REIMANN C \& ÖHMANN M eds, Migrants and the making of the urban-maritime world: agency and mobility in port cities, c. 1570-1940. Abingdon: Routledge 2020. 175-98.

118 LV Z, Les confréries et l'intégration des immigrants à Avignon (XIVe-XVe siècles). HU 591 (2020) 201-16.

119 MUSARRA A, Economic migrants or commuters? A note on the crews of Genoese galleys in the medieval Mediterranean, 14th-15th centuries. In FOLIN M \& MUSARRA A eds, Cultures and practices of coexistence from the thirteenth through the seventeenth centuries. Abingdon: Routledge 2020. $62-76$.

120 NAUMAN S, 'You cannot pass': the reception and rejection of a stranger in Helsingborg, 1744. In REIMANN C \& ÖHMANN M eds, Migrants and the making of the urban-maritime world: agency and mobility in port cities, c. 1570-1940. Abingdon: Routledge 2020. 130-54.

121 ÖHMANN M, New York City friends of industry and foreign migrants, c. 1815-1842. In REIMANN C \& ÖHMANN M eds, Migrants and the making of the urban-maritime world: agency and mobility in port cities, c. 1570-1940. Abingdon: Routledge 2020. 62-86.

122 PENNYBACKER S, 'Fire by night, cloud by day': exile and refuge in postwar London. JBS 591 (2020) $1-31$.

123 PRESTEL J B, Epilogue: what do histories of migration tell us about port cities? In REIMANN C \& ÖHMANN M eds, Migrants and the making of the urban-maritime world: agency and mobility in port cities, c. 1570-1940. Abingdon: Routledge 2020. 274-90.

124 REGNARD C, The transit stage as a migratory experience: the Syrians in Marseille (1880-1920). In REIMANN C \& ÖHMANN M eds, Migrants and the making of the urban-maritime world: agency and mobility in port cities, c. 1570-1940. Abingdon: Routledge 2020. 155-74.

125 TREMML-WERNER B, Migrant agencies in the early modern Manila Bay. In REIMANN C \& ÖHMANN M eds, Migrants and the making of the urban-maritime world: agency and mobility in port cities, c. 1570-1940. Abingdon: Routledge 2020. 17-42.

\section{Family and household structure}

126 LINDSTRÖM D, Families and households, tenants and lodgers: cohabitation in an early modern Swedish town, Linköping 1750-1800. JFH 452 (2020) 228-49. 
127 SOLAREVIĆ M, ĐURDEV B, LUKIĆ T, ĐERČAN B \& DUNJIĆ J, The historical-demographic heritage of the Ottoman and Austro-Hungarian empires through marriage patterns in Serbia: the case of Sremska Mitrovica and Šabac, 1900 to 2011. JFH 454 (2020) 479-97.

\section{Physical structure}

\section{Research methods, aids and materials}

128 GILLOT L, DEL A \& BOUET O, Ruines et humanités numériques. Reconstitution de l'histoire d'une ville-oasis. Le cas de Figuig (Maroc). HU 581 (2020) 103-32.

129 HERMELING A D, Look up, look down: discrepant stories from the Old Eighth Ward. PH 871 (2020) 203-11.

130 MCKINNEY A, The Edinburgh graveyard project: rebuilding monuments. BOEC 161 (2020) 109-10.

131 MALONE P, Bourdieu in London. JA 256 (2020) 679-96.

132 VARET-VITU A, MARRAUD M \& MERMET E, Spatialités sociales à Paris à la veille de la Révolution. Les apports d’un système d'information géographique. HU 581 (2020) 157-86.

133 VERDONCK L, LAUNARO A, VERMEULEN F \& MILLETT M, Ground-penetrating radar survey at Falerii Novi: a new approach to the study of Roman cities. A 94375 (2020) 705-23.

\section{Physical and structural characteristics of towns}

134 BAICS G, The social geography of near and far: built environment and residential distance in mid-nineteenth-century New York City. UH 473 (2020) 512-34.

135 CHEYETTE B, The ghetto: a very short introduction. Oxford: Oxford University Press 2020. pp 168.

136 COLSON J, Reinterpreting space: mapping people and relationships in late medieval and early modern English cities using GIS. UH 473 (2020) 384-400.

137 FISHER F, LARA-BETANCOURT P, KELLEY V \& SPARKE P, Complex interior spaces in London, 1850-1930: introduction. LJ 452 (2020) 177-88.

138 GARON S, On the transnational destruction of cities: what Japan and the United States learned from the bombing of Britain and Germany in the Second World War. P \& P 2471 (2020) 235-71.

139 GAUTHIEZ B, What mapping reveals: silk and the reorganization of urban space in Lyons, c. 16001900. UH 473 (2020) 448-66.

\section{Physical and structural characteristics of areas}

140 FULLILOVE M T, Main Street: how a city's heart connects us all. New York: New Village Press 2020. pp 352 .

141 PRATS G, ANTOLÍN F \& ALONSO N, From the earliest farmers to the first urban centres: a socio-economic analysis of underground storage practices in north-eastern Iberia. A 94375 (2020) 653-68.

\section{Architecture}

142 ALAM J, Symptomatic architecture: markings of presence, difference, fear, and trauma. In FOLIN M $\&$ PORFYRIOU H eds, Controversial heritage and divided memories from the nineteenth through the twentieth centuries. Abingdon: Routledge 2020. 139-51.

143 ASLET W, Situating St Mary-le-Strand: the church, the city and the career of James Gibbs. ArchH 63 1 (2020) $77-110$. 
144 AVIDE E, The birth of mass transit system or the imperative of technology: a look back at the design of suburban train stations in the 1970s. PlP 356 (2020) 1081-95.

145 BORTOLUCI J H, Brutalism and the people: architectural articulations of national developmentalism in mid-twentieth-century São Paulo. CSSH 622 (2020) 296-326.

146 BRISTOW M, The pre-industrial Lowestoft fish office: reading socio-political events through a vernacular building. VA 511 (2020) 1-22.

147 CHOI D N, Risk and fun: Dan Kiley's interior landscape for the Ford Foundation. SHGD 402 (2020) 95-109.

148 CHUN J-S, Imaginary Athens: urban space and memory in Berlin, Tokyo, and Seoul. Abingdon: Routledge 2020. pp 402.

149 CLERICUZIO P, Art nouveau and bank architecture in Nancy: negotiating the re-emergence of a French regional identity. ArchH 631 (2020) 219-56.

150 COLLINS J, The architecture and landscape of health: a historical perspective on therapeutic places 1790-1940. Abingdon: Routledge 2020. pp 218.

151 CONLEY T D, Urban architecture in interwar Yugoslavia. Abingdon: Routledge 2020. pp 230.

152 COOPER N, Holland House: architecture in an elite society. ArchH 631 (2020) 37-75.

153 DAVIS J, Avoiding white elephants? The planning and design of London's 2012 Olympic and Paralympic venues, 2002-2008. PlP 355 (2020) 827-48.

154 DELÉPINE M \& LEWIS W, Des villes et leurs stades olympiques. Regards croisés sur Colombes (1924) et Los Angeles (1932). HU 571 (2020) 67-85.

155 DODSON M S, Bureaucracy, belonging, and the city in North India 1870-1930. Abingdon: Routledge 2020. pp 248.

156 EMERY K, Architecture, space and memory: liturgical representation of Thomas Becket, 1170-1220. JBAA 1731 (2020) 61-77.

157 ERBEN D, Architecture. In TLUSTY B A \& HÄBERLEIN M eds, A companion to late medieval and early modern Augsburg. Leiden: Brill 2020. 526-52.

158 FARBØL R, Welfare or warfare? Civil defence in Danish urban welfare architecture. In BROOK R, DODGE M \& HOGG J eds, Cold War cities: politics, culture and atomic urbanism, 1945-1965. Abingdon: Routledge 2020. 196-212.

159 FERNÁNDEZ-GONZÁLEZ L, Architectural hybrids? Building, law and architectural design in the early modern Iberian world. RS 344 (2020) 550-71.

160 FISHER F, Inside London's railway termini, c. 1870-1939. LJ 452 (2020) 211-39.

161 GIUSTINO C M, The ghetto and the castle: modern urban design and knowledge transfer in historic Prague before and after 1918. In GANTNER E, HEIN-KIRCHER H \& HOCHADEL O eds, Interurban knowledge exchange in southern and eastern Europe, 1870-1950. Abingdon: Routledge 2020. 23-48.

162 GRINSELL S, Mastering the Nile? Confidence and anxiety in D. S. George's photographs of the First Aswan Dam, 1899-1912. EnH 251 (2020) 110-33.

163 GRUBER S D, The Brunner Plan for the Harrisburg Capitol complex. PH 871 (2020) 155-63.

164 HOPKINS J, The (dis)assembling of form: revealing the ideas built into Manchester's Medical School. JHMAS 751 (2020) 24-53.

165 HULTZSCH A, From encyclopaedia to magazine: the Loudons, the public and the architect in 1830s Britain. JA 257 (2020) 844-72. 
166 JASPER S, Acoustic ecologies: architecture, nature, and modernist experimentation in West Berlin. AAAG 1104 (2020) 1114-33.

167 LANG J, The Routledge companion to twentieth and early twenty-first century urban design: a history of shifting manifestoes, paradigms, generic solutions, and specific designs. Abingdon: Routledge 2020. pp 448.

168 LAWRENCE R, Halls, lobbies, and porches: transition spaces in Victorian architecture. JA 254 (2020) 419-43.

169 LAY P, Don't be evil. HT 703 (2020) 3.

170 LOADER N J, MILES D, MCCARROLL D, YOUNG G H F, DAVIES D, BRONK RAMSEY C \& JAMES J G, Oxygen isotope dating of oak and elm timbers from the portcullis windlass, Byward Tower, Tower of London. JASc 1161 (2020) 1-5.

171 MAGNE M, Architecture thermale et patrimoine princier en Bohême. Le Herrenhaus de Teplitz à la fin du XVIIIe siècle. HU 571 (2020) 157-78.

172 MAHER A, Reconstructing modernism: British literature, modern architecture, and the state. Oxford: Oxford University Press 2020. pp 272.

173 MANSBRIDGE J, Architecture, infrastructure, and urban performance in Hong Kong. ThJ 722 (2020) 197-218.

174 MARDELL J, Getting into a scrape: the Buckler dynasty, Lincoln Cathedral and mid-Victorian architectural politics. ArchH 631 (2020) 191-218.

175 MARIOTTI J, In-between the East and the West: architecture and urban planning in 'Non-Aligned' Skopje. In BROOK R, DODGE M \& HOGG J eds, Cold War cities: politics, culture and atomic urbanism, 1945-1965. Abingdon: Routledge 2020. 160-75.

176 MASOM G, Local churches in new urban Britain, 1890-1975: 'the greatest challenge'? London: Palgrave Macmillan 2020. pp xxi +288.

177 NIELSEN K H, Atomic urbanism under Greenland's ice cap: Camp Century and Cold War architectural imagination. In BROOK R, DODGE M \& HOGG J eds, Cold War cities: politics, culture and atomic urbanism, 1945-1965. Abingdon: Routledge 2020. 176-95.

178 OESTMANN G, The astronomical clock of Strasbourg Cathedral. Leiden: Brill 2020. pp xvi +348 .

179 OSBORNE J, Rome in the eighth century: a history in art. Cambridge: Cambridge University Press 2020. pp 312.

180 PILAV A, 'Architects in war': wartime destruction and architectural practice during the siege of Sarajevo. JA 256 (2020) 697-716.

181 PRUITT J A, Building the caliphate: construction, destruction, and sectarian identity in early Fatimid architecture. New Haven: Yale University Press 2020. pp 216.

182 PUECH V, La demeure urbaine aristocratique à Byzance (IVe-XVe siècles). HU 571 (2020) 133-55.

183 RAYNSFORD A, Educating a 'creative class': anti-disciplinary school architecture in the early 1970s. ChP 132 (2020) 138-52.

184 REILLY L, Roger II and medieval visual culture. In WINKLER E A, FITZGERALD L \& SMALL A eds, Designing Norman Sicily: material culture and society. Woodbridge: Boydell \& Brewer 2020. 23-46.

185 SANTIAGO J, Epigraphic workshops in Sigüenza Cathedral (Guadalajara, Spain) in the late Middle Ages. PMA 541 (2020) 60-77.

186 SMITH A, The expansion and remodelling of the London Hospital by Rowland Plumbe, 1884-1919. LJ 452 (2020) 270-98. 
187 SODERSTROM M, Concrete: from ancient origins to a problematic future. Regina: University of Regina Press 2020. pp 272.

188 SPARKE P, 'Covered promenades for wet weather': London's winter gardens and people's palaces, 1870-1900. LJ 452 (2020) 240-69.

189 STEMPNIAK K, Dressing the Eiffel Tower: fashion and architecture in fin de siècle Paris. FHS 432 (2020) 253-70.

190 TABANELLI M, Beyond 'plan bénédictin': reconsidering Sicilian and Calabrian cathedrals in the age of the Norman county. In WINKLER E A, FITZGERALD L \& SMALL A eds, Designing Norman Sicily: material culture and society. Woodbridge: Boydell \& Brewer 2020. 166-83.

191 TEMPLE N, Architecture and the language debate: artistic and linguistic exchanges in early modern Italy. Abingdon: Routledge 2020. pp 280.

192 URBAN F, Postmodern architecture under socialism: the Ascension Church in Warsaw - Ursynów. JA 253 (2020) 317-46.

193 WITTMANN R, Architecture in the Roman periodical press, 1770-1848. JA 257 (2020) 809-43.

\section{Housing}

194 ABRAMS L, KEARNS A, HAZLEY B \& WRIGHT V, Glasgow: high-rise homes, estates and communities in the post-war period. Abingdon: Routledge 2020. pp 144.

195 ALGER A, Homes for the poor? Public housing and the social construction of space in Baghdad, 1945-1964. JUH 465 (2020) 1142-57.

196 BIBBY P, HENNEBERRY J \& HALLEUX J-M, Under the radar? 'Soft' residential densification in England, 2001-2011. EPB 471 (2020) 102-18.

197 BONOMO B, The St Francis housing project: rituals, symbols and discourses in housing policies in Rome after the Second World War. In GUNN S \& HULME T eds, New approaches to governance and rule in urban Europe since 1500. Abingdon: Routledge 2020. 127-48.

198 BRADY J \& MCMANUS R, Dublin's twentieth-century social housing policies: tenure, 'reserved areas' and housing type. PlP 356 (2020) 1005-30.

199 CHAPPELL M, The strange career of urban homesteading: low-income homeownership and the transformation of American housing policy in the late twentieth century. JUH 464 (2020) 747-74.

200 CHOI W Y K, CHAN A HN \& CHAN A KW, Producing 'luxury' housing: developers' strategies and housing advertisements in Hong Kong (1961-2011). US 5716 (2020) 3252-80.

201 DEL BIANCO C, Pemba: spontaneous living spaces. Abingdon: Routledge 2020. pp 126.

202 DENNIS R, Toronto's early apartment houses: a micro-geography. In CLEMENTE A, LINDSTRÖM D \& STOBART J eds, Micro-geographies of the western city, c. 1750-1900. Abingdon: Routledge 2020. 15-35.

203 DUKANAC D \& BLAGOJEVIĆ L, Spaces of transition: testing high standard housing in late-socialist Belgrade. PlP 356 (2020) 969-1004.

204 FOX K, Sociology applied to planning: Robert K. Merton and the Columbia-Lavanburg housing study. JPH 194 (2020) 281-313.

205 HABIBI R, Modern middle-class housing in Tehran: reproduction of an archetype: episodes of urbanism 1945-1979. Leiden: Brill 2020. pp xvi +214. 
206 HARRIS N \& EDELSTEIN T J, Chicago apartments: a century and beyond of lakefront luxury. Chicago: University of Chicago Press 2020. pp 368.

207 HULME T, Urban materialities: citizenship, public housing and governance in modern Britain. In GUNN S \& HULME T eds, New approaches to governance and rule in urban Europe since 1500. Abingdon: Routledge 2020. 189-210.

208 HWANG S W \& KIM H-J, The intensifying gated exclusiveness of apartment complex boundary design in Seoul, Korea. PlP 354 (2020) 719-29.

209 JENKINS M \& STOBART J, The shop and the home: commercial and domestic space in eighteenthcentury England. In CLEMENTE A, LINDSTRÖM D \& STOBART J eds, Micro-geographies of the western city, c. 1750-1900. Abingdon: Routledge 2020. 55-72.

210 JUNG Y \& CINN E, Conflicting ideals and realities: the architecture of South Korea's first high-rise housing complex. JA 256 (2020) 736-58.

211 KALLIS A, 'Minimum dwelling' All'italiana: from the Case Popolari to the 1929 'model houses' of Garbatella. JUH 463 (2020) 603-21.

212 KALYUKIN A \& KOHL S, Continuities and discontinuities of Russian urban housing: the Soviet housing experiment in historical long-term perspective. US 578 (2020) 1768-85.

213 KING C, Houses and society in Norwich, 1350-1660: urban buildings in an age of transition. Woodbridge: Boydell \& Brewer 2020. pp 330.

214 KOURY A P, Modern housing estates and the production of the Brazilian city (1937-1960). PlP 354 (2020) 657-87.

215 LANGEN U, Representing a disreputable house. In CLEMENTE A, LINDSTRÖM D \& STOBART J eds, Micro-geographies of the western city, c. 1750-1900. Abingdon: Routledge 2020. 73-86.

216 MCCULLOCH M, Workers' housing and houses: interwar planning from Dessau to Detroit. JPH 19 4 (2020) 314-35.

217 MARTIN A M \& BEZEMER P M, The concept and planning of public native housing estates in Nairobi/Kenya, 1918-1948. PlP 354 (2020) 609-34.

218 MICHNEY T M \& WINLING L, New perspectives on New Deal housing policy: explicating and mapping HOLC loans to African Americans. JUH 461 (2020) 150-80.

219 PAWSON H, MILLIGAN V \& YATES J, Housing policy in Australia: a case for system reform. London: Palgrave Macmillan 2020. pp xvii +368.

220 PULLAN N, Temporary dwellings as informal suburban development in the global North and the case of Sydney 1945-1960. PlP 351 (2020) 193-209.

221 ROMYN M, London's Aylesbury estate: an oral history of the 'concrete jungle'. London: Palgrave Macmillan 2020. pp xiv +310 .

222 SIEGMUNT O, The historical development of the housing policy of Russian cities from preindustrialization period to the free real estate market. PlP 356 (2020) 955-68.

223 SMITH R K, Death and rebirth in a southern city: Richmond's historic cemeteries. Baltimore, MD: Johns Hopkins University Press 2020. pp 328.

224 SNYDER R W, Sounding the powers of place in neighborhoods: responses to the urban crisis in Washington Heights and New York City. JUH 466 (2020) 1290-316.

225 SORESINA M, The housing struggle in Milan in the 1970s: influences and particularities. JUH 466 (2020) 1386-406. 
226 TAGESSON G, The brilliant idea of the bookkeeper Johan Peter Frisk and the coming of an urban wooden housing culture in Linköping, Sweden. In CLEMENTE A, LINDSTRÖM D \& STOBART J eds, Micro-geographies of the western city, c. 1750-1900. Abingdon: Routledge 2020. 36-54.

227 TARANTA I, Development of a post-medieval residential building at 15 Złota Street, Tykocin, Poland. PMA 543 (2020) 251-64.

228 URBAN F, Postmodernism and socialist mass housing in Poland. PlP 351 (2020) 27-60.

229 WANG N, YANG E \& LI L, Time as space: a comparative analysis of Zhejiang traditional houses in the 1960s and 2010s. JA 251 (2020) 77-109.

\section{Social life}

230 DE CRUZ A F, The experience of war. In TLUSTY B A \& HÄBERLEIN M eds, A companion to late medieval and early modern Augsburg. Leiden: Brill 2020. 342-66.

\section{Heritage and the historic environment}

231 AULT B, The Commonwealth Memorial: a new sculpture for the Capitol grounds. PH 871 (2020) $225-32$.

232 BĂDESCU G, Cosmopolitan heritage? Post-war reconstruction and urban imaginaries in Sarajevo and Beirut. In FOLIN M \& PORFYRIOU H eds, Controversial heritage and divided memories from the nineteenth through the twentieth centuries. Abingdon: Routledge 2020. 120-38.

233 BARKER A, CRAWFORD A, BOOTH N \& CHURCHILL D, Park futures: excavating images of tomorrow's urban green spaces. US 5712 (2020) 2456-72.

234 BARNARD K A, The Mercers' Company, London, and St Thomas Becket during the Reformation. $L J$ 453 (2020) 299-317.

235 BELMESSOUS S, Commemorating French colonialism in Australia: on the Lapérouse monument in Sydney. HA 173 (2020) 471-88.

236 BORDELEAU A, Urban monuments in diverse cities. In FOLIN M \& PORFYRIOU $\mathrm{H}$ eds, Controversial heritage and divided memories from the nineteenth through the twentieth centuries. Abingdon: Routledge 2020. 10-27.

237 BUTLER R J, The afterlives of Galway jail, 'difficult' heritage, and the Maamtrasna murders: representations of an Irish urban space, 1882-2018. IHS 44166 (2020) 295-325.

238 CASTAÑEDA LÓPEZ C \& VELA COSSÍO F, The imprint of the Spanish tobacco industry on the urban landscape: permanences and absences of an industrial memory. IAR 421 (2020) 16-28.

239 COIGNET P \& HALLYNCK A, Between heritage and the contemporary. Three paradoxes of the Minimes barracks, Paris. SHGD 40 3-4 (2020) 353-7.

240 COLLA M, Memory, heritage and the demolition of the Potsdam Garisonkirche, 1968. GeH 382 (2020) 290-310.

241 DA HORA J F, PORTO V C, MAGALHÃES W \& ALENCASTO E, Unveiling regional archaeological heritage, historical archaeology at Vale do Ribeira: the case of Sobrado dos Toledos, Iguape-São Paulo. IJHA 243 (2020) 707-27.

242 DARLINGTON J, Fake heritage: why we rebuild monuments. New Haven: Yale University Press 2020. pp 248.

243 DAVOINE C, Les ruines contre la ville. L'idéal urbain à l'épreuve des destructions dans le monde romain. HU 581 (2020) 15-28. 
244 DE LA VAISSIÈRE E, Inherited landscapes in Muslim Bactra. In DURAND-GUÉDY D, MOTTAHEDEH R \& PAUL J eds, Cities of medieval Iran. Leiden: Brill 2020. 124-41.

245 DEVECKA M, Broken cities: a historical sociology of ruins. Baltimore, MD: Johns Hopkins University Press 2020. pp 184.

246 DODD A, MILESON S \& WEBLEY L eds, The archaeology of Oxford in the 21st century: investigations in the city by Oxford Archaeology, 2006-16. Woodbridge: Boydell \& Brewer 2020. pp 464.

247 DUNGWORTH D \& ANDREWS P, The Thames Plate Glass Company, Leamouth, London: archaeological and technical investigations. PMA 542 (2020) 133-64.

248 ESFAHANI A S, The fortified landscape of Isfahan. In DURAND-GUÉDY D, MOTTAHEDEH R \& PAUL J eds, Cities of medieval Iran. Leiden: Brill 2020. 177-216.

249 FANTA V, ZOUHAR J, BENEŠ J, BUMERL J \& SKLENICKA P, How old are the towns and villages in central Europe? Archaeological data reveal the size of bias in dating obtained from traditional historical sources. JASC 1131 (2020) 1-10.

250 GARCÉS FELIÚ E, ROSAS VERA J, PÉREZ VILLALÓN E \& PARDO DE CASTRO J C, Urban modernization and heritage in the historic centre of Santiago de Chile (1818-1939). PlP 351 (2020) 91-113.

251 GILLOT L \& GUILHEMBET J-P, Villes en ruine, ruines en ville dans l'Antiquité romaine et au-delà. HU 581 (2020) 5-13.

252 GRYTA J, Jews and Poles in the Holocaust exhibitions of Kraków, 1980-2013: between urban past and national memory. London: Palgrave Macmillan 2020. pp xiii +148.

253 HARVEY A D, Remaining traces of the Blitz in London. LocH 502 (2020) 127-33.

254 HASIAN M \& PALIEWICZ N, Memory and monument wars in American cities: New York, Charlottesville and Montgomery. London: Palgrave Macmillan 2020. pp v + 152.

255 HERRMANN J T \& SCONZO P, Planning Punic cities: geophysical prospection and the built environment at Motya, Sicily. A 94376 (2020) 983-98.

256 HICKMAN R, Uses of maritime heritage: the twenty-first-century life of the Newport medieval ship. IJHerS 264 (2020) 401-14.

257 KALAKOSKI I, HUUHKA S \& KOPONEN O-P, From obscurity to heritage: canonisation of the Nordic wooden town. IJHerS 268 (2020) 790-805.

258 KUMAR V, When heritage meets creativity: a tale of two urban development strategies in Kampong Glam, Singapore. CitC 192 (2020) 398-420.

259 LÄHDESMÄKI T, Politics of belonging in Brussels' European quarter. IJHerS 2610 (2020) 979-97.

260 LARKIN K, Decolonizing Ludlow: a study in participatory archaeology. IJHA 241 (2020) 156-82.

261 LEGG G, 'The buildings are screaming': the spatial politics of terrorism in London. $L J 451$ (2020) $1-16$.

262 MORVILLEZ E, La conscience des ruines dans l'Antiquité tardive. Entre vécu et représentations. $H U$ $581(2020) 29-58$.

263 O'CONNELL C, 'Poor, proud and pretty' community history and the challenge of heritage in 'darkest' Cheltenham. IJRLH 151 (2020) 48-69.

264 PALIOURA M-M, 'Trikoupis refuses to unveil himself in order not to see.' A memorial statue and national identity in early 20th-century Greece. In LOUKAKI A ed, Urban art and the city: creating, destroying, and reclaiming the sublime. Abingdon: Routledge 2020. 177-92. 
265 PANETTA C, 'Digging in the water?' Grassroots urbanism, the Egyptian state, and the politics of heritage-making in post-revolution Cairo. IJHerS 2612 (2020) 1221-39.

266 PELEGRÍN M A, Spanish Rome and Roman Spain: reconstructing the past of Rome and Cordova in early modern Rome. In FOLIN M \& MUSARRA A eds, Cultures and practices of coexistence from the thirteenth through the seventeenth centuries. Abingdon: Routledge 2020. 189-207.

267 PICKIN R, 'Stand in the place of those executed': interpreting capital punishment in UK prison museums. In LOW P, RUTHERFORD H \& SANDFORD-COUCH C eds, Execution culture in nineteenth century Britain: from public spectacle to hidden ritual. Abingdon: Routledge 2020. 98-118.

268 POMFRET D M, Battle for the peak: childhood, the Great War and cultural heritage tourism in Hong Kong. CulSH 17 (2020) 677-96.

269 SCHOFIELD J, The archaeology of terrorism: damage to two medieval churches in the City of London in the IRA attacks of 1992 and 1993. LJ 451 (2020) 86-105.

270 SHAPLAND M, Capturing the spirit of singular places: a biographical approach to historic building recording. PMA 541 (2020) 18-41.

271 SILVERMAN H, The Inca in the plaza: debating change in the World Heritage historic urban centre of Cusco, Peru. IJHerS 2611 (2020) 1092-108.

272 STEVENS Q, Cities and memory: a history of the role of memorials in urban design from the Renaissance to Canberra. PlP 353 (2020) 401-31.

273 WHITCOMB D, 'From Shahristān to Medina' revisited. In DURAND-GUÉDY D, MOTTAHEDEH R \& PAUL J eds, Cities of medieval Iran. Leiden: Brill 2020. 77-99.

274 WOLLENTZ G, Landscapes of difficult heritage. London: Palgrave Macmillan 2020. pp xvii + 297.

275 WYLER S, Des villes et des ruines dans les Satyrica, de Pétrone à Fellini. HU 581 (2020) 59-80.

276 ZHANG M \& LENZER JR. J H, Mismatched canal conservation and the authorised heritage discourse in urban China: a case of the Hangzhou section of the Grand Canal. IJHerS 262 (2020) 105-19.

\section{Social structure}

\section{Research methods, aids and materials}

277 HART S M \& HOMSY G C, Stories from north of Main: neighborhood heritage story mapping. IJHA 244 (2020) 950-68.

278 LOGAN F D, The register of Simon Sudbury, archbishop of Canterbury, 1375-1381. Woodbridge: Boydell \& Brewer 2020. pp 391.

279 VAN DEN HEUVEL D, PIERIK B, AMARO B V \& KISJES I, Capturing gendered mobility and street use in the historical city: a new methodological approach. CulSH 174 (2020) 515-36.

\section{Social organization, clubs and societies}

280 COLLINGE P, Enterprise, activism and charity: Mary Pickford and the urban elite of Derby, 17801812. MidH 451 (2020) 36-54.

281 MATTES J, Talking about popular science in the metropolis: learned societies, multiple publics, and spatial practices in Vienna (1840-1900). In ASH M G ed, Science in the metropolis: Vienna in transnational context, 1848-1918. Abingdon: Routledge 2020. 170-95.

282 SIMONOW J, The great Bengal Famine in Britain: metropolitan campaigning for food relief and the end of empire, 1943-44. JICH 481 (2020) 168-97. 
283 STALLER K M, New York's newsboys: Charles Loring Brace and the founding of the Children's Aid Society. Oxford: Oxford University Press 2020. pp 406.

284 WHEELER M, The Athenaeum: more than just another London club. New Haven: Yale University Press 2020. pp 440.

\section{Class structure}

285 BAGUET J, The transformation of an urban political elite: oligarchy and aristocracy in sixteenthcentury Ghent. UH 474 (2020) 632-47.

286 HÄBERLEIN M \& REITH R, Urban society: inequality, poverty, and mobility. In TLUSTY B A \& HÄBERLEIN M eds, A companion to late medieval and early modern Augsburg. Leiden: Brill 2020. 271-93.

287 LAWRENCE A M, Morals and mignonette; or, the use of flowers in the moral regulation of the working classes in high Victorian London. JHG 701 (2020) 24-35.

288 LEE S-J, Canteens and the politics of working-class diets in industrial China, 1920-37. MAsS 541 (2020) 1-29.

289 ROUSSET I, Representing the 'other' Berlin, c. 1900: micro-geographies of the proletarian city. In CLEMENTE A, LINDSTRÖM D \& STOBART J eds, Micro-geographies of the western city, c. 17501900. Abingdon: Routledge 2020. 144-61.

290 SALA A R, Social mobility and service to the crown in late medieval Catalonia (c. 1350-c. 1420): an approach centred on the area of Girona. HU 581 (2020) 133-56.

\section{Social life}

291 BOWERS C, 'Men who loved their fellow mortals': blood donor recruitment, identity and motivation in Edinburgh, 1930-1939. BOEC 161 (2020) 63-76.

292 BRÉE S, Where did the first divorced people live in Paris and its suburbs. HF 253 (2020) 345-68.

293 BUYLAERT F, BAGUET J \& EVERAERT J, Returning urban political elites to the research agenda: the case of the Southern Low Countries (c. 1350-c. 1550). UH 474 (2020) 568-88.

294 BUYLAERT F, From periphery to centre and back again: elite transformations in Mechelen (fourteenth to sixteenth centuries). UH 474 (2020) 610-31.

295 ÇELIK F, Neighbourhood's surveillance of margins: negotiating limits of social exclusion in early modern Istanbul (1530s-1590s). In FOLIN M \& MUSARRA A eds, Cultures and practices of coexistence from the thirteenth through the seventeenth centuries. Abingdon: Routledge 2020. 133-45.

296 CH'IEN L, Polytopos in early modern Venetian imagery. In FOLIN M \& MUSARRA A eds, Cultures and practices of coexistence from the thirteenth through the seventeenth centuries: multi-ethnic cities in the Mediterranean world, vol. I. Abingdon: Routledge 2020. 118-32.

297 COUPERUS S, The people of new Jerusalem: narratives of social in- and exclusion in Rotterdam after the Blitz of 1940. In KINDERMANN M \& ROHLEDER R eds, Exploring the spatiality of the city across cultural texts: narrating spaces, reading urbanity. London: Palgrave Macmillan 2020. 167-83.

298 DOWDALL A, Communities under fire: urban life at the Western Front, 1914-1918. Oxford: Oxford University Press 2020. pp 272.

299 FERNÁNDEZ-SORDO A S, 'Not such an unfriendly land': contacts and reception of foreigners in the port towns of Asturias in the Middle Ages. HU 591 (2020) 217-38.

300 FOLIN M \& PORFYRIOU H, The multi-ethnic heritage of Mediterranean cities. In FOLIN M \& PORFYRIOU H eds, Controversial heritage and divided memories from the nineteenth through the twentieth centuries. Abingdon: Routledge 2020. 1-9. 
301 FÖLLMER M, The sociology of individuality and the history of urban society. UH 472 (2020) $311-26$.

302 FROST D \& CATNEY G, Belonging and the intergenerational transmission of place identity: reflections on a British inner-city neighbourhood. US 5714 (2020) 2833-49.

303 GAYER L \& KIRMANI N, 'What you see is what you get': local journalism and the search for truth in Lyari, Karachi. MAsS 545 (2020) 1483-525.

304 GHOSH N, A hygienic city-nation: space, community, and everyday life in colonial Calcutta. Cambridge: Cambridge University Press 2020. pp 236.

305 GULIZIA S, The career of Alfonso Ulloa (1529-1570) in early modern Venice: a cosmopolitan outlook of the 16th-century book trade. In FOLIN M \& MUSARRA A eds, Cultures and practices of coexistence from the thirteenth through the seventeenth centuries. Abingdon: Routledge 2020. 208-18.

306 HANSEN C S, Visions of the north-west: making a working-class neighbourhood in Copenhagen, Denmark, 1900-1950. SJH 454 (2020) 479-505.

307 LARKIN $\mathrm{T}$ M, 'White' undesirables: socio-cultural hierarchies and racial anxiety in early-twentieth-century Shanghai. CulSH 172 (2020) 207-25.

308 LIDDY C D, Family, lineage and dynasty in the late medieval city: re-thinking the English evidence. UH 474 (2020) 648-70.

309 MCREE B R, Honesty and dissent: resisting the Company of St George in Tudor Norwich. UH 471 (2020) 23-40.

310 MAUDLIN D, Inns and elite mobility in late Georgian Britain. $P$ \& $P 2471$ (2020) 37-76.

311 ÖZTANER E, A glimpse on the different ethnic communities living in an Istanbul neighbourhood, the Mahalle-i Mâ'mûre. In FOLIN M \& MUSARRA A eds, Cultures and practices of coexistence from the thirteenth through the seventeenth centuries. Abingdon: Routledge 2020. 146-65.

312 PANAYI P, Migrant city: a new history of London. New Haven: Yale University Press 2020. pp 384.

313 PETKOV K, Integrating the foreigner: the strategy of inclusion in Renaissance Venice. In FOLIN M \& MUSARRA A eds, Cultures and practices of coexistence from the thirteenth through the seventeenth centuries. Abingdon: Routledge 2020. 101-17.

314 RUVOLDT M, Gossip and reputation in sixteenth-century Rome: Tommaso de'Cavalieri and Lavinia della Valle. RS 343 (2020) 374-91.

315 SANDERS J C, Razing kids: youth, environment, and the postwar American West. Cambridge: Cambridge University Press 2020. pp 290.

316 SELIGMAN S D, The great kosher meat war of 1902: immigrant housewives and the riots that shook New York City. Lincoln, NE: University of Nebraska Press 2020. pp 312.

317 SNYDER-GRENIER E M, The house on Henry Street: the enduring life of a lower east side settlement. New York: New York University Press 2020. pp 256.

318 STAICOV A, Creating belonging in San Francisco Chinatown's diasporic community: morphosyntactic aspects of indexing ethnic identity. London: Palgrave Macmillan 2020. pp xiii + 182.

319 VAN DER STEEN B, VAN ROODEN C \& SNOEP M, Who are the squatters? Challenging stereotypes through a case study of squatting in the Dutch city of Leiden, 1970-1980. JUH 466 (2020) 1368-85.

320 WALTON C, Taking control: gossip, community and conflict in Basford Union workhouse 1836 to 1871. FCH 231 (2020) 23-41. 


\section{Social life, customs and traditions}

321 CHARALAMBOUS N, Spatial forms of ethnic coexistence in Ottoman Cyprus: the role of urban form in patterns of everyday life. JUH 463 (2020) 579-602.

322 CHILD P, Blacktown, Mass-Observation, and the dynamics of Voluntary Action in mid-twentieth-century England. HJ 623 (2020) 754-76.

\section{Religion}

323 ADANKPO-LABADIE O, A faith between two worlds: expressing devotion and crossing cultural boundaries at Santo Stefano dei Mori in early modern Rome. In WAINWRIGHT M C \& MICHELSON E eds, A companion to religious minorities in early modern Rome. Leiden: Brill 2020. 169-90.

324 AIGLE D, Among saints and poets: the spiritual topography of medieval Shiraz. In DURAND-GUÉDY D, MOTTAHEDEH R \& PAUL J eds, Cities of medieval Iran. Leiden: Brill 2020. $142-76$.

325 BAZELON B S, The trek uptown: the migration of Harrisburg's Jewish community in the early twentieth century. PH 871 (2020) 179-91.

326 BERNSTEIN H J, The reformed terreur panique of 1562: debating miracles and memory in seventeenth-century Le Mans. FH 344 (2020) 475-92.

327 BOLES R J, Dividing the faith: the rise of segregated churches in the early American North. New York: New York University Press 2020. pp 344.

328 BUTLER J, God in Gotham: the miracle of religion in modern Manhatten. Cambridge MA: Belknap Press 2020. pp 320.

329 CLINES R J, Pope as arbiter: the place of early modern Rome in the pan-Mediterranean ecumenical visions of Eastern Rite Christians. In WAINWRIGHT M C \& MICHELSON E eds, A companion to religious minorities in early modern Rome. Leiden: Brill 2020. 55-88.

330 DI NEPI S, A new source and a working hypothesis on slavery, conversion and religious minorities in early modern Rome (16th-19th centuries). In WAINWRIGHT M C \& MICHELSON E eds, A companion to religious minorities in early modern Rome. Leiden: Brill 2020. 272-97.

331 DIEFENDORF B B, The scars of religious war in histories of French cities (1600-1750). FH 344 (2020) 453-74.

332 FOSI I, Between conversion and reconquest: the Venerable English College between the late 16th and 17th centuries. In WAINWRIGHT M C \& MICHELSON E eds, A companion to religious minorities in early modern Rome. Leiden: Brill 2020. 115-41.

333 FOSI I, Inquisition, conversion, and foreigners in Baroque Rome. Leiden: Brill 2020. pp vi +260 .

334 FUJIKAWA M, Papal ceremonies for the embassies of non-Catholic rulers. In WAINWRIGHT M C \& MICHELSON E eds, A companion to religious minorities in early modern Rome. Leiden: Brill 2020. 13-54.

335 HANSON M Z, The urban Reformation. In TLUSTY B A \& HÄBERLEIN M eds, A companion to late medieval and early modern Augsburg. Leiden: Brill 2020. 221-46.

336 HARRISON C E, Conversion in the age of mechanical reproduction: Alphonse Ratisbonne in Rome and Paris. JModH 921 (2020) 116-44.

337 HEPWORTH J, Between isolation and integration: religion, politics, and the Catholic Irish in Preston, c. 1829-1868. I \& $M 38$ 1-2 (2020) 77-104.

338 HERRICK S K, 'Very great strife': the monks of Saint-Clément as competitors in twelfth-century Metz. JMH 465 (2020) 536-51. 
339 HILL J, Rome in Ripon: St Wilfrid's inspiration and legacy. H 105367 (2020) 603-25.

340 HOLLAND B, Self and city in the thought of Saint Augustine. London: Palgrave Macmillan 2020. pp $\mathrm{xxi}+162$.

341 HUNT E, Dispatches from Baghdad: sectarian war in Iraq, 2006-2007. MES 561 (2020) 100-15.

342 IHNAT K, The martyrs of Córdoba: debates around a curious case of medieval martyrdom. HC 181 (2020) 1-15.

343 JENKINS J, St Thomas Becket and medieval London. H 105367 (2020) 652-72.

344 JONES M, St Mary's, Southwell, and the archbishops of York, c. 1100-1540. NH 571 (2020) 3-19.

345 KASSIK H, The medieval calendars of S. Pietro in Vaticano and S. Maria Maggiore in Rome. In HEIKKILÄ $\mathrm{T}$ ed, Time in the Eternal City: perceiving and controlling time in late medieval and Renaissance Rome. Leiden: Brill 2020. 159-219.

346 LUKKARI J, The jubilee of 1300 as an instrument of time control and papal power. In HEIKKILÄ T ed, Time in the Eternal City: perceiving and controlling time in late medieval and Renaissance Rome. Leiden: Brill 2020. 59-105.

347 MCFARLAND J, Relics, reinvention, and reform in Renaissance Venice: Catherine of Siena's stigmata at the Basilica dei Santi Giovanni e Paolo. RS 342 (2020) 278-302.

348 MCGOVERN B P, Andrew Jackson and the Protestant Irish of Philadelphia: early nineteenth-century sectarianism. PH 872 (2020) 313-37.

349 MCKITTERICK R, Rome and the invention of the papacy: the Liber Pontificalis. Cambridge: Cambridge University Press 2020. pp 288.

350 MICHELSON E, Resist, refute, redirect: Roman Jews attend conversionary sermons. In WAINWRIGHT M C \& MICHELSON E eds, A companion to religious minorities in early modern Rome. Leiden: Brill 2020. 349-74.

351 MINGOUS G, Forging memory: the aftermath of the Saint Batholomew's Day massacre in Lyon. FH 344 (2020) 435-52.

352 NGO T T T, Dynamics of memory and religious nationalism in a Sino-Vietnamese border town. MAsS 543 (2020) 795-829.

353 NOVOA J N, Being a new Christian in early modern Rome. In WAINWRIGHT M C \& MICHELSON E eds, A companion to religious minorities in early modern Rome. Leiden: Brill 2020. 192-236.

354 OUSTERHOUT R G, Museum or mosque? Istanbul's Hagia Sophia has been a monument to selective readings of history. HT 709 (2020) 22-4.

355 PLATT A, Love manifested as unity and division; baptist identity at Romney Street baptist church, 1815-1854. BQ 514 (2020) 142-62.

356 PLUMMER M E \& TLUSTY B A, Catholic-Protestant coexistence. In TLUSTY B A \& HÄBERLEIN M eds, A companion to late medieval and early modern Augsburg. Leiden: Brill 2020. 247-70.

357 POLAND P, 'Parish pumps' - the role of the Church of Ireland in Cork City in early fire-fighting. Hire 282 (2020) 18-21.

358 RENSHAW D, The queen's loyal 'others' - the metropolitan Jewish and Catholic hierarchies, the communal press and the Diamond Jubilee of 1897. I \& M 383 (2020) 184-204.

359 RIOLI M C, A liminal church: refugees, conversions and the Latin diocese of Jerusalem, 1946-1956. Leiden: Brill 2020. pp xiv +387 . 
360 SANTUS C, Wandering lives: eastern Christian pilgrims, alms-collectors and 'refugees' in early modern Rome. In WAINWRIGHT M C \& MICHELSON E eds, A companion to religious minorities in early modern Rome. Leiden: Brill 2020. 237-71.

361 SHOHAM-STEINER E, Towers and lions? Identifying the patron of a medieval illuminated mahzor from Cologne. JeH 332 (2020) 245-73.

362 SINGER M F, Faith in beauty and progress: Temple Beth El. PH 871 (2020) 97-107.

363 STIEVERMANN J, A 'syncretism of piety': imagining global Protestantism in early eighteenthcentury Boston, Tranquebar, and Halle. ChH 894 (2020) 829-856.

364 TAO B, The chrysanthemum and the 'saint': Kagawa's statue in the Washington National Cathedral. ChH 893 (2020) 567-91.

365 TRAMONTANA F, Geographical mobility and community-building in seventeenth-century Palestine: insights from the records of Bethlehem's Catholic parish. ContC 352 (2020) 163-85.

366 VAN KESSEL E, The making of a hybrid body: Corpus Christi in Lisbon, 1582. RS 344 (2020) 572-92.

367 WANG L, Medieval saints and their miraculous songs: ritual singing, funerary piety, and the construction of female sanctity in thirteenth-century Liège. ChH 893 (2020) 509-30.

368 WATT J R, The consistory and social discipline in Calvin's Geneva. Woodbridge: Boydell \& Brewer 2020. pp 338.

369 WEI I P, Thinking about animals in thirteenth-century Paris: theologians on the boundary between humans and animals. Cambridge: Cambridge University Press 2020. pp 237.

370 WELLINGS M, 'The day of compromise is past': the Oxford Free Churches and 'passive resistance' to the 1902 Education Act. SCH 561 (2020) 455-70.

371 YENIKLER S S, The cultural transformation of Genoese Galata from the Byzantine to the Ottoman rule. In FOLIN M \& MUSARRA A eds, Cultures and practices of coexistence from the thirteenth through the seventeenth centuries. Abingdon: Routledge 2020. 77-100.

\section{Recreation}

372 BELL S W, Horse racing in imperial Rome: athletic competition, equine performance, and urban spectacle. IJHS 37 3-4 (2020) 183-232.

373 CARRERAS M, Getting wet and cleaning up: swimming, social class, and space in 1950s Barcelona. IJHS 37 1-2 (2020) 113-34.

374 CARTER J, The Shanghai race club. HT 7010 (2020) 58-65.

375 DOMINGOS N, L'urbanisation coloniale et la citoyenneté sportive. Le processus de 'sportivisation' à Lourenço Marques, Mozambique. HU 571 (2020) 87-108.

376 HAYNES R, From sporting past to future well-being: sport heritage and intergenerational learning in Glasgow. SpiH 402 (2020) 257-77.

377 JASER C, Urban palio and scharlach races in fifteenth- and early sixteenth-century Italy and Germany. IJHS 37 3-4 (2020) 272-87.

378 LE BAS A, Ceque Paris doit au sport. Essai de topographie parisienne des équipements. HU 571 (2020) 23-45.

379 PASSAVANT E \& SOREZ J, Le ballon de la discorde. Sociohistoire du football dans l'espace public urbain. HU 571 (2020) 109-31.

380 ROTAR M, Developing rugby in interwar Romania: the case of provincial cities and towns. SpiH 402 (2020) 207-34. 
381 SCHUT P-O, BEAUDOUIN S \& PHILIPPE M, Interaction between Olympism and host cities: the example of Paris. IJHS 3714 (2020) 1443-65.

382 SOREZ J, Le sport, l'histoire et la ville. La fin d'un espace scientifique segmenté? HU 571 (2020) $5-21$.

383 TAYLOR M \& VILLE S, Un marché pugilistique franco-anglais. Histoire transnationale de l'organisation des spectacles de boxe à Londres et à Paris (1880-1920). HU 571 (2020) 47-66.

384 TLUSTY B A, Sociability and leisure. In TLUSTY B A \& HÄBERLEIN M eds, A companion to late medieval and early modern Augsburg. Leiden: Brill 2020. 316-41.

\section{Social problems and deviance}

385 BACH M, Combating London's criminal class: a state divided, 1869-95. London: Bloomsbury Academic 2020. pp 208.

386 BAER A S, Beyond the usual beating: the Jon Burge police torture scandal and social movements for police accountability in Chicago. Chicago: University of Chicago Press 2020. pp 312.

387 BEAVAN B \& SEITER M, Regulating sin in the city: the moral geographies of naval port towns in Britain and Germany, c. 1860-1914. BatW 131 (2020) 27-46.

388 CHAZKEL A, Toward a history of rights in the city at night: making and breaking the nightly curfew in nineteenth-century Rio de Janeiro. CSSH 621 (2020) 106-34.

389 CLEMENT W, The Christ in the cabaret: putting a blasphemous bar crawl on trial in Third Republic France. CulSH 172 (2020) 189-205.

390 CREASMAN A F, Crime and punishment. In TLUSTY B A \& HÄBERLEIN M eds, A companion to late medieval and early modern Augsburg. Leiden: Brill 2020. 171-95.

391 HORNER D, Trouble at the edge of town: policing Montreal's urban periphery in the middle of the nineteenth century. In CLEMENTE A, LINDSTRÖM D \& STOBART J eds, Micro-geographies of the western city, c. 1750-1900. Abingdon: Routledge 2020. 206-21.

392 JOHANSEN A, Beyond the reach of law? Criminal prosecution of Parisian police personnel, 18721914. JModH 923 (2020) 485-520.

393 LEBRÓN M, They don't care if we die: the violence of urban policing in Puerto Rico. JUH 465 (2020) 1066-84.

394 MCLEOD J \& GIRARD R, Policing printers and booksellers before and after 1789: a case study in Bordeaux. FH 341 (2020) 22-42.

395 MUURLING S, Everyday crime, criminal justice and gender in early modern Bologna. Leiden: Brill 2020. pp x +254 .

396 NEALE A, Photographing crime scenes in twentieth-century London: microhistories of domestic murder. London: Bloomsbury Academic 2020. pp 232.

397 PURDUE O, Nineteenth-century Nimbys, or what the neighbour saw? Poverty, surveillance, and the boarding-out of Poor Law children in late nineteenth-century Belfast. FCH 232 (2020) 119-35.

398 RASPA D A, Bloody bay: grassroots policing in nineteenth-century San Francisco. Lincoln, NE: University of Nebraska Press 2020. pp 318.

399 WHITE M, Formulations of the nineteenth-century London execution crowd: fears, fictions and realities. In LOW P, RUTHERFORD H \& SANDFORD-COUCH C eds, Execution culture in nineteenth century Britain: from public spectacle to hidden ritual. Abingdon: Routledge 2020. 58-78. 


\section{Social reforms and improvement}

400 AGEE C L, Crisis and redemption: the history of American police reform since World War II. JUH 465 (2020) 951-60.

401 CHRONOPOULOS T, The making of the orderly city: New York since the 1980s. JUH 465 (2020) 1085-116.

\section{Minority groups}

402 ALLWOOD A, Belonging in Brixton: an ethnography of migrant West Indian elders in Brixton, London. London: Palgrave Macmillan 2020. pp xxxi +321.

403 ARAUJO A L, Afterword: ghosts of slavery. IRSH 65 S28 (2020) 225-36.

404 BEAVEN B, Foreign sailors and working-class communities: race, crime, and moral panics in London's Sailortown, 1880-1914. In REIMANN C \& ÖHMANN M eds, Migrants and the making of the urbanmaritime world: agency and mobility in port cities, c. 1570-1940. Abingdon: Routledge 2020. 87-108.

405 BOROWSKI T, Jews in Famagusta: spatial and visual seclusion under Italian rule in the Levant. In FOLIN M \& MUSARRA A eds, Cultures and practices of coexistence from the thirteenth through the seventeenth centuries. Abingdon: Routledge 2020. 40-61.

406 BURNARD T, Slaves and slavery in Kingston, 1770-1815. IRSH 65 S28 (2020) 39-65.

407 CANDIDO M P, The expansion of slavery in Benguela during the nineteenth century. IRSH 65 S28 (2020) 67-92.

408 CASIMIRO T M, HENRIQUES J P, FILIPE V \& SIMÕES S, Mobility and identities: the case of the so-called African pots from Lisbon (Portugal). IJHA 241 (2020) 79-94.

409 CHENG W, Landscapes of beauty and plunder: Japanese American flower growers and an elite public garden in Los Angeles. EPD 384 (2020) 699-717.

410 CHUA J Y, The strange career of gross indecency: race, sex, and law in colonial Singapore. $L \& H R 38$ 4 (2020) 699-735.

411 COUNCIL A, Ringing Liberty's Bell: African American women, gender, and the underground railroad in Philadelphia. PH 873 (2020) 494-531.

412 DAEN L, 'To board \& nurse a stranger': poverty, disability, and community in eighteenth-century Massachusetts. JSocH 533 (2020) 716-41.

413 DHUPELIA-MESTHRIE U, Waiting on Cape Town in the apartheid era: life histories of Indian waiters and barmen. SH 454 (2020) 522-47.

414 DOUGHERTY D M, Urban redevelopment, school closure, and the abstract space of black schooling in Prince George's County, Maryland, 1968-1972. JUH 465 (2020) 1117-41.

415 DOYLE D, A load off whose heart? Psychiatry and the politics of respectability and race representation in Harlem, 1943-45. JHMAS 751 (2020) 54-82.

416 EISENSTADT P, 'Neighborliness is nonspatial': Howard Thurman and the search for integration and common ground. JUH 466 (2020) 1206-21.

417 FATAH-BLACK K, Introduction: urban slavery in the age of abolition. IRSH 65 S28 (2020) 1-14.

418 FORREST A, Remembering and forgetting: how France's slaving ports have come to terms with their past. HC 1810 (2020) 1-8.

419 GLENNON K, Facts and fallacies of the Belfast pogrom. Hire 285 (2020) 28-31.

420 GONZALES D-J, El Cine Yost and the power of place for Mexican migrants in Orange County, California, 1930-1990. JAEH 394 (2020) 42-59. 
421 HARDESTY J R, Disappearing from abolitionism's heartland: the legacy of slavery and emancipation in Boston. IRSH 65 S28 (2020) 145-68.

422 HAYES C, Decline in the era of triumph: black workers in 1960s New York City. LabH 61 5-6 (2020) 486-502.

423 HIRSCH S \& SWANSON D, Photojournalism and the Moss Side Riots of 1981: narrowly selective transparency. HWJ 891 (2020) 221-45.

424 HØGSBJERG C, Globalising the Haitian Revolution in black Paris: C.L.R. James, metropolitan antiimperialism in interwar France and the writing of The black Jacobins. JICH 483 (2020) 491-519.

425 KARAÖMERLIOĞLU M A \& KOUROU N S, Where faith meets modernity: cemevi and local Alevi politics. MES 566 (2020) 839-53.

426 KENNERLEY S, Ethiopian Christians in Rome, c. 1400-1700. In WAINWRIGHT M C \& MICHELSON E eds, A companion to religious minorities in early modern Rome. Leiden: Brill 2020. 142-68.

427 KLOOSTER W, Comparative perspectives on the urban black Atlantic on the eve of abolition. IRSH 65 S28 (2020) 15-37.

428 KRZYZANOWSKI L, Ghost citizens: Jewish return to a postwar city. Cambridge MA: Harvard University Press 2020. pp 352.

429 LASNER M G, Segregation by design: race, architecture, and the enclosure of the Atlanta apartment. JUH 466 (2020) 1222-60.

430 LEVY J A, Black Power, Inc.: global American business and the post-apartheid city. ES 214 (2020) $866-74$.

431 MCQUARRIE M, Race, participation, and institutional transformation in the neoliberal city: black politics in Cleveland, 1965-2010. In DIAMOND A J \& SUGRUE T J eds, Neoliberal cities: the remaking of postwar urban America. New York: New York University Press 2020. 173-206.

432 MAJID A, Imagining Bradford: Islam, space, and anxiety in Multitudes and Combustion. ThJ 723 (2020) 309-23.

433 MANZ S \& BENBOW M E, Counter-propaganda and spy fever: Germans in Washington, DC, during World War I. JAEH 401 (2020) 40-69.

434 MÜLLER V F, Runaway slaves in antebellum Baltimore: an urban form of marronage? IRSH 65 S28 (2020) 169-95.

435 MÜLLER V F, Early undocumented workers: runaway slaves and African Americans in the urban South, c. 1830-1860. LabH 612 (2020) 90-106.

436 MURCH D, The color of war: race, neoliberalism, and punishment in late twentieth-century Los Angeles. In DIAMOND A J \& SUGRUE T J eds, Neoliberal cities: the remaking of postwar urban America. New York: New York University Press 2020. 128-53.

437 NASAR S \& SCHAFFER G, The poetic of narrativity: understanding trauma, temporality, and spatiality forty years after the Birmingham pub bombings. JSocH 534 (2020) 1008-32.

438 NORTH S, Remembering slavery in urban Cape Town: emancipation or continuity? IRSH 65 S28 (2020) 197-223.

439 NZINDUKIYIMANA O, 'That's Jean Lowe': on being a black Canadian female track athlete in 1940s Toronto. IJHS 3714 (2020) 1371-87.

440 PLUSKOTA M, Freedom of movement, access to the urban centres, and abolition of slavery in the French Caribbean. IRSH 65 S28 (2020) 93-115. 
441 RITTER L, Immigration, crime, and the economic origins of political nativism in the Antebellum West. JAEH 392 (2020) 62-91.

442 SÁNCHEZ G J, A community decides who belongs: local democracy and incorporating the undocumented in Boyle Heights, 1970s-1990s. JAEH 394 (2020) 60-74.

443 SAVAGE M, Beyond boundaries: envisioning metropolitan school desegregation in Boston, Detroit, and Philadelphia, 1963-1974. JUH 461 (2020) 129-49.

444 SCHNEIDER E C, The ecology of homicide: race, place, and space in postwar Philadelphia. Philadelphia: University of Pennsylvania Press 2020. pp 264.

445 SCHNEIDER E C, AGEE C \& CHRONOPOULOS T, Dirty work: police and community relations and the limits of liberalism in postwar Philadelphia. JUH 465 (2020) 961-79.

446 SCHRADER S, More than cosmetic changes: the challenges of experiments with police demilitarization in the 1960s and 1970s. JUH 465 (2020) 1002-25.

447 ULLMANN S, Jews as ethnic and religious minorities. In TLUSTY B A \& HÄBERLEIN M eds, A companion to late medieval and early modern Augsburg. Leiden: Brill 2020. 367-88.

448 VAN BOXEL P, Jews in 16th-century Italy and the vicissitudes of the Hebrew book. In WAINWRIGHT M C \& MICHELSON E eds, A companion to religious minorities in early modern Rome. Leiden: Brill 2020. 324-48.

449 VAZ M, Running the numbers: race, police, and the history of urban gambling. Chicago: University of Chicago Press 2020. pp 208.

450 WALDEN J A, Muslim slaves in early modern Rome: the development and visibility of a labouring class. In WAINWRIGHT M C \& MICHELSON E eds, A companion to religious minorities in early modern Rome. Leiden: Brill 2020. 298-323.

451 WIGGINS D, 'Order as well as decency': the development of order maintenance policing in black Atlanta. JUH 464 (2020) 711-27.

452 WILLIAMS J K, Trouble the water: The Baltimore to New Orleans coastwise slave trade, 1820-1860. SaA 412 (2020) 275-303.

453 WILLIAMS R Y, Places created and peopled: 'black women: where they be...suffering?' JUH 463 (2020) 478-89.

454 YA'AKOV M B, Middle Eastern Jews and the urban ecology of a late Ottoman Palestine. In FOLIN M \& PORFYRIOU H eds, Controversial heritage and divided memories from the nineteenth through the twentieth centuries. Abingdon: Routledge 2020. 44-62.

\section{Family life}

455 ALBISETTI J C, Sending city children to the country: vacations in 'nature' ca. 1870-1900. PaedH 56 $1-2(2020) 70-84$.

456 DANTAS M L R \& LIBBY D C, Families, manumission, and freed people in urban Minas Gerais in the era of Atlantic abolitionism. IRSH 65 S28 (2020) 117-44.

457 DELAMEILLIEURE C \& HAEMERS J, Recalcitrant brides and grooms: jurisdiction, marriage and conflicts with parents in fifteenth-century Ghent. In ARMSTRONG J W \& FRANKOT E eds, Cultures of law in urban northern Europe: Scotland and its neighbours c. $1350-$ c. 1650. Abingdon: Routledge 2020. 154-71.

458 FARRELL Z, The materiality of marriage in the artisan community of Renaissance Verona. HJ 622 (2020) 243-66. 
459 TAYLOR S J, Children, poverty and mental health in rural and urban England (1850-1907). RH 312 (2020) 151-64.

460 TERPSTRA N, Abandoned children of the Italian Renaissance: orphan care in Florence and Bologna. Baltimore, MD: Johns Hopkins University Press 2020. pp 368.

\section{Gender}

461 BATZELL R \& COFFMAN S, Infanticide and abandonment in the industrial metropolis: gender, reproduction and capitalism in Chicago, 1870-1911. G \& H 323 (2020) 581-601.

462 BEATTIE I, Class analysis and the killing of the newborn child: Manchester, 1790-1860. HWJ 891 (2020) 45-67.

463 CHAN Y-K, Creating modern women: the kitchen in postcolonial Singapore, 1960-90. JSeAS 513 (2020) 414-34.

464 CHAND A, Belonging to Glasgow and Clydeside in the Second World War: retrieving regional subjectivities among male civilian workers. CulSH 174 (2020) 537-67.

465 CONLEY C A, Debauched, desperate, deranged: women who killed, London 1674-1913. Oxford: Oxford University Press 2020. pp 240.

466 DAVIDSON R, A local perspective: the women's movement and citizenship, Croydon 1890s-1939. WomHR 296 (2020) 1016-33.

467 DAWSON V S, Shares, shirts and soap suds: women and rugby league football in Liverpool, 19341950. SpiH 404 (2020) 530-51.

468 FREELAND J, Gendering value change: domestic violence and feminism in 1970s West Berlin. GeH $384(2020) 638-55$.

469 GLAZE A, Sanctioned and illicit support networks at the margins of a Scottish town in the early seventeenth century. SH 451 (2020) 26-51.

470 GÓMEZ-GALVARRIATO A, Female entrepreneurship as a survival strategy: women during the early mechanisation of corn tortilla production in Mexico City. ContC 351 (2020) 75-103.

471 GREEFS H \& WINTER A, Foreign female sex workers in an Atlantic port city: elite prostitution in late nineteenth-century Antwerp. In REIMANN C \& ÖHMANN M eds, Migrants and the making of the urbanmaritime world: agency and mobility in port cities, c. 1570-1940. Abingdon: Routledge 2020. 199-226.

472 HUTCHINSON E J, Sex, knowledge and 'women of sin' in the Registre criminel du Châtelet de Paris (1389-92). G \& H 321 (2020) 131-48.

473 JAMES G, Establishing women in sports history: Manchester City football club. SpiH 404 (2020) 434-55.

474 JASANI R, Violence, urban anxieties and masculinities: the 'foot soldiers' of 2002, Ahmedabad. Sas 434 (2020) 675-90.

475 JENKINS E, Elite colored women: the material culture of photography \& Victorian era womanhood in reconstruction era Memphis. SaA 411 (2020) 29-63.

476 KIMOURTZIS P \& SIGOUNTOU V, When protons were gendered: women in the School of Physics and Mathematics of the University of Athens (1922-1967). PaedH 565 (2020) 787-806.

477 LATIN I B, Female piety and gendered spaces: women's hospitals in Renaissance Dubrovnik. In CRAWSHAW J L S, LATIN I B \& VONGSATHORN K eds, Tracing hospital boundaries: integration and segregation in southeastern Europe and beyond, 1050-1970. Leiden: Brill 2020. 213-45.

478 LAZAROMS I J, Humanitarian encounters: charity and gender in post-World War I Jewish Budapest. JeH 331 (2020) 115-32. 
479 LEWIS M, Women, family, and sexuality. In TLUSTY B A \& HÄBERLEIN M eds, A companion to late medieval and early modern Augsburg. Leiden: Brill 2020. 294-315.

480 MANEKIN R, From Anna Kluger to Sarah Schenirer: women's education in Kraków and its discontents. JEH 331 (2020) 29-59.

481 MCLELLAND K, Sexual and economic constructions of women's lameness in the Norwich poor census. EMW 151 (2020) 95-106.

482 MCNEICE A O, Bored bluestockings and frivolous flirts: dynamics of gender and the experiences of the first female students of Queen's College Cork, 1879-1910. ISR 284 (2020) 445-62.

483 MINCHINTON B, Female crews: sex workers in nineteenth-century Melbourne. HA 172 (2020) 346-64.

484 MONTENACH A, Coping with economic uncertainty: women's work and the protoindustrial family in eighteenth-century Lyon. ContC 351 (2020) 33-52.

485 MOSS E, Sexual harassment, victimhood and affective self-fashioning in Victorian England: the Bolton Workhouse Scandal, 1889-1890. G \& H 322 (2020) 465-81.

486 OLIVEIRA V S, The business of self-endowment: women merchants, wealth and marriage in nineteenth-century Luanda. In ASTON J \& BISHOP C eds, Female entrepreneurs in the nineteenth century: a global perspective. London: Palgrave Macmillan 2020. 219-42.

487 OMAN G, Segregation, regulation, and the gendering of space at the University of Wales, Bangor, 1884-1907. WomHR 292 (2020) 308-30.

488 PEDERSEN S, Caroline Phillips: balancing life as a journalist and a suffragette in a Scottish city. WomHR 296 (2020) 940-54.

489 PLUSKOTA M, Governing sexuality: regulating prostitution in early modern Europe. In GUNN S \& HULME T eds, New approaches to governance and rule in urban Europe since 1500. Abingdon: Routledge 2020. 85-107.

490 POUTANEN M A \& OLSON S, Public houses and hidden networks: roles of women in midnineteenth century Montreal. In CLEMENTE A, LINDSTRÖM D \& STOBART J eds, Micro-geographies of the western city, c. 1750-1900. Abingdon: Routledge 2020. 162-82.

491 SHITRIT L B, Women and the Holy City: the struggle over Jerusalem's sacred space. Cambridge: Cambridge University Press 2020. pp 222.

492 SORIA M, Geographies of urban female labor and nationhood in Spanish culture, 1880-1975. Lincoln, NE: University of Nebraska Press 2020. pp 354.

493 STEINHOFF J, Gendering prayer in Trecento Florence: tomb paintings in Santa Croce and San Remigio. In PERKINSON S \& TUREL N eds, Picturing death 1200-1600. Leiden: Brill 2020. 64-78.

494 WHELEHEN N, Saving Ireland in Juteopolis: gender, class and diaspora in the Irish Ladies' Land League. HWJ 901 (2020) 74-95.

\section{Sexualities}

495 ALCALDE M D R \& MARTÍ X P, Women, football, and Francoism: lesbians and the formation of social networks through women's football in Barcelona, 1970-1979. IJHS 37 1-2 (2020) 94-112.

496 COOK M, Local matters: queer scenes in 1960s Manchester, Plymouth, and Brighton. JBS 591 (2020) 32-56.

497 GIESEKING J J, A queer New York: geographies of lesbians, dykes, and queers. New York: New York University Press 2020. pp 336. 
498 HARDWICK J, Sex in an old regime city: young workers and intimacy in France, 1660-1789. Oxford: Oxford University Press 2020. pp 288.

499 HEMPHILL K M, Bawdy city: commerical sex and regulation in Baltimore, 1790-1915. Cambridge: Cambridge University Press 2020. pp 352.

500 LVOVSKY A, Cruising in plain view: clandestine surveillance and the unique insights of antihomosexual policing. JUH 465 (2020) 980-1001.

\section{Economic activity}

\section{Urban economic activity}

501 ADAMS T, 'New life, new vigor, and new value': privatization, service work, and the rise of neoliberal urbanism in postwar southern California. In DIAMOND A J \& SUGRUE T J eds, Neoliberal cities: the remaking of postwar urban America. New York: New York University Press 2020. 49-77.

502 ALCORN K, From specimens to commodities: the London nursery trade and the introduction of exotic plants in the early nineteenth century. HR 93262 (2020) 715-33.

503 ANDREWS A, Dereliction, decay and the problem of de-industrialization in Britain, c. 1968-1977. UH 472 (2020) 236-56.

504 APELLÁNIZ F, Breaching the Bronze Wall: Franks at Mamluk and Ottoman courts and markets. Leiden: Brill 2020. pp $\mathrm{x}+332$.

505 BAILEY M, Urban disruption, suburbanization and retail innovation: establishing shopping centres in Australia. UH 471 (2020) 152-69.

506 BESSARD F, Caliphs and merchants: cities and economies of power in the Near East (700-950). Oxford: Oxford University Press 2020. pp 400.

507 BLACKMORE R, The effects of commercial privileges in late medieval Bordeaux, 1348-1449. FH 34 $1(2020) 1-21$.

508 CESARETTI R, LOBO J, BETTENCOURT L M A \& SMITH M E, Increasing returns to scale in the towns of early Tudor England. HM 533 (2020) 147-65.

509 CROMPTON J L, Using proximate real estate to fund England's nineteenth century pioneering urban parks: viable vehicle or mendacious myth? SHGD 401 (2020) 43-64.

510 CROSSLEY P K, China normal: patterns of urbanization, industrialization, and trade on a Eurasian discursive base. MAsS 544 (2020) 1278-314.

511 EDIGER V S \& BOWLUS J V, Greasing the wheels: the Berlin-Baghdad railway and Ottoman oil, 1888-1907. MES 562 (2020) 193-206.

512 EIBEN J, 'A horizon of national economic opportunity' - industrialization and crisis in 1970s Wilhelmshaven. UH 472 (2020) 257-73.

513 EPSTEIN S, 'The police cannot be present at every transaction': regulating marketplace meetings between taxi drivers and passengers in Asheville, North Carolina, 1914-1922. JUH 462 (2020) 364-82.

514 EVERETT S S, Une ambiance diaspora: continuity and change in Parisian Maghrebi imaginaries. CSSH 621 (2020) 135-55.

515 FOWLER J, Compensating the passengers. A comparison of the management of three London underground crashes 1909-1975. BuH 628 (2020) 1324-40.

516 FRANCOIS M, 'Se Mantiene de Lavar': the laundry business in eighteenth- and nineteenth-century Mexico City. In ASTON J \& BISHOP C eds, Female entrepreneurs in the nineteenth century: a global perspective. London: Palgrave Macmillan 2020. 33-55. 
517 FRANK S, Industrial networks and urban development: Kansas City's film row district and national film distribution. B \& L 271 (2020) 46-64.

518 GOLDSTONE J A, Urbanization, citizenship, and economic growth in the long run. IRSH 651 (2020) 109-24.

519 GOREN T, The development gap between the cities of Jaffa and Tel Aviv and its effect on the weakening of Jaffa in the time of the Mandate. MES 566 (2020) 900-13.

520 HILL S, Georgian Liverpool's northern whaling trade reconsidered: ranking, significance and geography. IJMH 324 (2020) 808-22.

521 KARN N, England's trade with the continent in the early thirteenth century: customs and the port of Dover. JMH 463 (2020) 306-34.

522 KIPNIS A B \& CLIFF T, Chinese economies in ethnographic perspective: two case studies of intersecting socioeconomic diversity. MAsS 546 (2020) 1987-2021.

523 KLEIN A \& CRAFTS N, Agglomeration externalities and productivity growth: US cities, 1880-1930. EcHR 731 (2020) 209-32.

524 KÜNAST H-J, Book production and trade. In TLUSTY B A \& HÄBERLEIN M eds, A companion to late medieval and early modern Augsburg. Leiden: Brill 2020. 415-39.

525 LEMMEN S, Bohemia by the sea: establishing a Czechoslovak port in Hamburg in the interwar period. EurRH 276 (2020) 809-23.

526 LEWIS S I, More than just penny capitalists: the range of female entrepreneurship in mid-nineteenth-century US cities. In ASTON J \& BISHOP C eds, Female entrepreneurs in the nineteenth century: a global perspective. London: Palgrave Macmillan 2020. 243-65.

527 MORCILLO M G, Mentality, motivation, and economic decision-making in Ancient Rome: Cicero and Tullia's shrine. EcHR 733 (2020) 623-43.

528 NAGATA M L, Japanese female entrepreneurs: women in Kyoto businesses in Tokugawa Japan. In ASTON J \& BISHOP C eds, Female entrepreneurs in the nineteenth century: a global perspective. London: Palgrave Macmillan 2020. 267-88.

529 PAPINI M, A 'veritable fairyland': Mikado Bazaar in Sunderland and the commodification of Japanese culture in the north east of England, 1861-1900. HRC 62 (2020) 97-117.

530 PHILLIPS-FEIN K, The politics of austerity: the moral economy in 1970s New York. In DIAMOND A J \& SUGRUE T J eds, Neoliberal cities: the remaking of postwar urban America. New York: New York University Press 2020. 78-97.

531 SAHLE E, Law and gospel order: resolving commercial disputes in colonial Philadelphia. ContC 353 (2020) 281-310.

532 SMITH H, BENNETT R J \& VAN LIESHOUT C, Entrepreneurship in Birmingham and Manchester, 1851-1911: a tale of two cities? MidH 453 (2020) 357-80.

533 TOMLINSON J, De-industrialization: strengths and weaknesses as a key concept for understanding post-war British history. UH 472 (2020) 199-219.

534 TOMS S, Financing cotton: British industrial growth and decline. Woodbridge: Boydell \& Brewer 2020. pp 334 .

535 ULIANOVA G, A mosaic of entrepreneurship: female traders in Moscow, 1810s-1850s. In ASTON J \& BISHOP C eds, Female entrepreneurs in the nineteenth century: a global perspective. London: Palgrave Macmillan 2020. 85-112. 
536 VERHOEVEN G, Clockwise? Timekeeping in London in the long eighteenth century (1724-1825). CulsH 174 (2020) 451-71.

537 VERHOEVEN G, Fashionably late? Time, work and the industrious revolution in early modern Antwerp (1585-1795). ContC 353 (2020) 255-79.

538 WARLOUZET L, The collapse of the French shipyard of Dunkirk and EEC state-aid control (197786). BuH 625 (2020) 858-78.

539 WRIGHT P D, The ballast trade: an economic driver in seventeenth- and eighteenth-century Newcastle upon Tyne. NH 571 (2020) 101-19.

540 ZONDERMAN A, Binding and unwinding the British empire: Philadelphia's German merchants as consumer and political revolutionaries. EAmS 183 (2020) 324-64.

\section{Industry}

541 ALEXANDER N, DOHERTY A M \& CRONIN J, Transformational retailing and the emergence of a modern brand: Liberty of London, 1875-1900. HRC 62 (2020) 78-96.

542 ARCHER-PARRÉ C, Places, spaces and the printing press: trade interactions in Birmingham. MidH 452 (2020) 145-60.

543 CASTRES A, La production de linge à Paris à l'ère des nouveautés (1520-1620): genre, techniques et innovations. FHS 432 (2020) 167-95.

544 CATALAN J \& FERNÁNDEZ-DE-SEVILLA T, Hierarchical clusters: emergence and success of the automotive districts of Barcelona and São Paulo. ES 212 (2020) 343-79.

545 LLONCH-CASANOVAS M, Immigrant entrepreneurs, technology transfer and knowledge spillovers: the case of Lyon Barcelona (1933-1981). BuH 627 (2020) 1162-81.

546 MASRANI S K, MCKIERNAN P \& MCKINLAY A, Strategic responses to low-cost competition: technological lock-in in the Dundee jute industry. BuH 626 (2020) 960-81.

547 NEUMANN A, From Fordist to neo-liberal urban spaces in times of de-industrialization: a conceptual frame for a complex relationship. UH 472 (2020) 220-2355.

548 PAJIC M, The fortunes of urban fullers in fourteenth-century England. HR 93260 (2020) 227-51.

549 PARERA A S, FERRER-ALÓS L, PUJOLÀ L V, YAMAMICHI Y, Silk textiles, crisis and adaptative strategies in Catalonia, 1770-1850s (Barcelona and Manresa). ContC 351 (2020) 53-74.

550 PHILLIPS J, WRIGHT V \& TOMLINSON J, Being a 'Clydesider' in the age of deindustrialisation: skilled male identity and economic restructuring in the west of Scotland since the 1960s. LabH 612 (2020) 151-69.

551 SJÖGREN G, Proclamation or persuasion? Promoting the Birmingham cut-nail trade, 1827-95. MidH 452 (2020) 222-43.

552 YILDIZ H, The politics of time in colonial Bombay: labor patterns and protest in cotton mills. JSocH $541(2020) 206-85$.

\section{Food supply}

553 BRUNMAYR N, Herring trade, quality controls and diplomacy in Cologne in the fifteenth century. $\mathrm{GeH} 384$ (2020) 527-49.

554 BUSTO-ZAPICO M, Standardization and units of measurement used in pottery production: the case of the post-medieval botijuela or Spanish olive jar made in Seville. PMA 541 (2020) 42-59.

555 DEFRANCE S D \& KENNEDY J R, The Finny Tribe: how coastal, cosmopolitan New Orleans satisfied an appetite for fish. IJHA 242 (2020) 367-97. 
556 GROOTE P \& TASSENAAR V, Living standards in a dairy region, 1850-1900: from urban penalty to urban premium. JHG 701 (2020) 12-23.

557 JAMES P, Food provisions for ancient Rome: a supply chain approach. Abingdon: Routledge 2020. pp 240.

558 ONGARO G, Military food supply in the Republic of Venice in the eighteenth century: entrepreneurs, merchants, and the state. BuH 628 (2020) 1255-78.

\section{Finance, banking and industry}

559 BARDYN A, Constrained opportunities: women's involvement in the capital markets of late medieval Brabant. SH 453 (2020) 275-303.

560 CRAIG B, A constant presence: the businesswomen of Paris, 1810-1880. In ASTON J \& BISHOP C eds, Female entrepreneurs in the nineteenth century: a global perspective. London: Palgrave Macmillan 2020. $113-36$.

561 HÄBERLEIN M, Production, trade, and finance. In TLUSTY B A \& HÄBERLEIN M eds, A companion to late medieval and early modern Augsburg. Leiden: Brill 2020. 101-22.

562 HEIN B, Old regime in a new world: Frankfurt's financial market in the nineteenth century. JModH $924(2020) 735-73$.

563 KUEHN T, Lorenzo de' Medici and inheritance law in Florence. RS 342 (2020) 243-59.

564 MARCHIEL R K, After redlining: the urban reinvestment movement in the era of financial deregulation. Chicago: University of Chicago Press 2020. pp 296.

565 MATHEW N, At the crossroads of empire and nation-state: partition, gold smuggling, and port cities in the western Indian Ocean. MAsS 543 (2020) 898-929.

566 VILLA C E V, Microfinances in the banking houses of Rio de Janeiro in 1864. BuH 623 (2020) 509-35.

567 WINTER M, The collapse of Thompson and Company: credit, reputation and risk in early modern England. SH 452 (2020) 145-66.

\section{Consumption}

568 BARTELS V \& BOND K, Dress and material culture. In TLUSTY B A \& HÄBERLEIN M eds, A companion to late medieval and early modern Augsburg. Leiden: Brill 2020. 440-69.

569 GILBERT J, Better dressed Birmingham'? Wholesale clothing catalogues and the communication of mass fashion, 1920s to 1960s. MidH 452 (2020) 258-74.

\section{Working conditions}

570 ARAZ Y \& KOKDAŞ I, In between market and charity: child domestic work and changing labor relations in nineteenth-century Ottoman Istanbul. ILWCH 971 (2020) 81-108.

571 BERNHARDT D E \& BERNSTEIN R, Ordinary people, extraordinary lives: a pictorial history of working people in New York City. New York: New York University Press 2020. pp 240.

572 BROWN D H L, GREEN D R, MCILVENNA K \& SHELTON N, The beating heart of the system: the health of postal workers in Victorian London. JHG 681 (2020) 75-85.

573 MCCABE C, Charwomen and Dublin's secondary labour force in the late nineteenth and early twentieth centuries. SH 452 (2020) 193-217.

574 SERRI N, The factory and the welfare state: redundancy, benefits and workers' organization at Alfa Romeo Arese, 1963-1986. LabH 611 (2020) 12-23.

575 STEPHENSON J Z, Contracts and pay: work in London construction 1660-1785. London: Palgrave Macmillan 2020. pp xxi +261. 
576 STEPHENSON J Z, Working days in a London construction team in the eighteenth century: evidence from St Paul's Cathedral. EcHR 732 (2020) 409-30.

577 SUNSERI C K, Alliance rises in the west: labor, race, and solidarity in industrial California. Lincoln, NE: University of Nebraska Press 2020. pp 174.

578 WONIAK K, Zwangswelten: emotions und alltagsgeschichte polnischer 'zivilarbeiter' in Berlin 19391945. Leiden: Brill 2020. pp viii +424.

\section{Labour organization}

579 DOBBS S \& LOH K S, Unsafety and unions in Singapore's state-led industrialization, 1965-1994. LabH 612 (2020) 107-21.

580 GIROD G, The women who make the guns: the munitionettes in Glasgow and Paris and their lack of interaction with the far-left agitators. LabH 612 (2020) 203-12.

581 QUINN S, Infrastructure, ethnicity, and political mobilization in Namibia, 1946-87. JAfrH 611 (2020) 45-66.

582 SCHLOSBERG R, The New York City tax rank-and-file coalition: 1971-1977. LabH 612 (2020) $170-85$.

583 SHTASEL R, Workers' resilience in occupied France: workers in Le Havre, 1941-1942. FH 342 (2020) 235-52.

584 VON BRIESEN B J, 'The guild...manufactures nothing, nor produces any artifact': Barcelona's seven maritime cargo handling guilds, c. 1760-1840. IRSH 653 (2020) 399-431.

\section{Communications}

\section{Inter-urban communications}

585 CANADELLI E, Crossing the Iron Curtain: Milan's Museum of Technology and transnational exchanges before and after World War II. In GANTNER E, HEIN-KIRCHER H \& HOCHADEL O eds, Interurban knowledge exchange in southern and eastern Europe, 1870-1950. Abingdon: Routledge 2020. $255-79$.

586 DODGE M \& BROOK R, Cold War telecommunication and urban vulnerability: underground exchange and microwave tower in Manchester. In BROOK R, DODGE M \& HOGG J eds, Cold War cities: politics, culture and atomic urbanism, 1945-1965. Abingdon: Routledge 2020. 299-315.

587 GANTNER E, HEIN KIRCHER H \& HOCHADEL O, Introduction: searching for best practices in interurban networks. In GANTNER E, HEIN-KIRCHER H \& HOCHADEL O eds, Interurban knowledge exchange in southern and eastern Europe, 1870-1950. Abingdon: Routledge 2020. 1-22.

588 HOCHADEL O, Going east: Gustave Loisel and the networks of exchange between zoological gardens before 1914. In GANTNER E, HEIN-KIRCHER H \& HOCHADEL O eds, Interurban knowledge exchange in southern and eastern Europe, 1870-1950. Abingdon: Routledge 2020. 188-210.

589 LAURSEN O B, 'I have only one country, it is the world': Madame Cama, anticolonialism, and Indian-Russian revolutionary networks in Paris, 1907-17. HWJ 901 (2020) 96-114.

590 MALLART L, Architectural conversations across Europe's borderlands. In GANTNER E, HEIN-KIRCHER H \& HOCHADEL O eds, Interurban knowledge exchange in southern and eastern Europe, 1870-1950. Abingdon: Routledge 2020. 211-29.

591 MAZANIK A, Learning from smaller cities: Moscow in the international urban networks, 18701910. In GANTNER E, HEIN-KIRCHER H \& HOCHADEL O eds, Interurban knowledge exchange in southern and eastern Europe, 1870-1950. Abingdon: Routledge 2020. 118-33. 
592 MIRALLES BUIL C, Improving health in a Mediterranean city: Barcelona and the European network (1931-1937). In GANTNER E, HEIN-KIRCHER H \& HOCHADEL O eds, Interurban knowledge exchange in southern and eastern Europe, 1870-1950. Abingdon: Routledge 2020. 154-64.

593 SPRING U, Polar waters in metropolitan space: circulating knowledge about the ice-free Arctic Ocean in Hamburg and Vienna. In ASH M G ed, Science in the metropolis: Vienna in transnational context, 1848-1918. Abingdon: Routledge 2020. 108-30.

594 WAGENAAR C, Afterword: goodbye to center and periphery. In GANTNER E, HEIN-KIRCHER H \& HOCHADEL O eds, Interurban knowledge exchange in southern and eastern Europe, 1870-1950. Abingdon: Routledge 2020. 280-92.

\section{Politics and administration Aspects of urban administration}

595 ANDREW P R \& BROWN I G, A halberdier at the piazza: John Myles and the city officer. BOEC 16 1 (2020) 93-102.

596 ARMSTRONG J W, 'Malice' and motivation for hostility in the burgh courts of late medieval Aberdeen. In ARMSTRONG J W \& FRANKOT E eds, Cultures of law in urban northern Europe: Scotland and its neighbours c. 1350 - c. 1650. Abingdon: Routledge 2020. 208-25.

597 AUSCHNER E, ÁLVAREZ L L \& PÉREZ L A, Paradiplomacy and city branding: the case of Medellín, Colombia (2004-2019). In AMIRI S \& SEVIN E eds, City diplomacy: current trends and future prospects. London: Palgrave Macmillan 2020. 279-303.

598 BALSAS C J L, A study of Porto's polycentric metropolitan development and governance at the turn of the millennium. IJRLH 152 (2020) 131-45.

599 BARBER B, The Wirrall family: Doncaster merchants, Yorkshire gentry, and settlers in Ulster, 15141641. YAJ 921 (2020) 98-114.

600 BIRD J, Fire in the Bronx: austerity, quality of life, and nightlife regulation in New York City post-1975. JUH 464 (2020) 836-53.

601 BROWN M H, The burgh and the forest: burgesses and officers in fifteenth-century Scotland. In ARMSTRONG J W \& FRANKOT E eds, Cultures of law in urban northern Europe: Scotland and its neighbours c. 1350 - c. 1650. Abingdon: Routledge 2020. 121-37.

602 BUTLER R J, Urban governance and prison building in pre-famine Ireland, 1820-1845. In GUNN S \& HULME T eds, New approaches to governance and rule in urban Europe since 1500. Abingdon: Routledge 2020. 44-63.

603 CARAWAN E, Control of the laws in the ancient democracy at Athens. Baltimore, MD: Johns Hopkins University Press 2020. pp 328.

604 CARMINATI L, Dividing and ruling a Mediterranean port-city: the many boundaries within late 19th century Port Said. In FOLIN M \& PORFYRIOU H eds, Controversial heritage and divided memories from the nineteenth through the twentieth centuries. Abingdon: Routledge 2020. 28-43.

605 CLERC L, Turku (Finland) as a case study in the city diplomacy of small urban centres, 1971-2011. In AMIRI S \& SEVIN E eds, City diplomacy: current trends and future prospects. London: Palgrave Macmillan 2020. 331-58.

606 CLOSE C W, Politics under the guild regime, 1368-1548. In TLUSTY B A \& HÄBERLEIN M eds, A companion to late medieval and early modern Augsburg. Leiden: Brill 2020. 123-45.

607 COLSON J, Reassessing power and governance in late medieval cities: institutions and the cursus honorum. In GUNN S \& HULME T eds, New approaches to governance and rule in urban Europe since 1500. Abingdon: Routledge 2020. 23-43. 
608 COUPERUS S \& WOLFFRAM D J, Negotiating urban governance: norm entrepreneurs in Dutch cities, 1850-1900. In GUNN S \& HULME T eds, New approaches to governance and rule in urban Europe since 1500. Abingdon: Routledge 2020. 108-26.

609 CRUICKSHANK J L, The wapentake courts of the honour of Pontefract, 1427-1877. NH 571 (2020) $20-42$.

610 DITCHBURN D, Bells, clocks and the beginnings of 'lawyer time' in late medieval Scotland. In ARMSTRONG J W \& FRANKOT E eds, Cultures of law in urban northern Europe: Scotland and its neighbours c. 1350 - c. 1650. Abingdon: Routledge 2020. 226-46.

611 DORAN G \& DORAN L, Shining a light on early town governance in New Ross. Hire 281 (2020) 8-9.

612 EASTOE S, Idiocy, imbecility and insanity in Victorian society: Caterham Asylum, 1867-1911. London: Palgrave Macmillan 2020. pp xvii +212.

613 ELKIN D, Backlash on the border: conservatism and the rise of the new economy in the San DiegoTijuana corridor. JUH 463 (2020) 561-78.

614 ELLIS R, London and its asylums, 1888-1914. London: Palgrave Macmillan 2020. pp xv + 296.

615 ELRICK J W, Simulating renewal: postwar technopolitics and technological urbanism. EPD 386 (2020) 1120-37.

616 EVERAERT J, Power in the metropolis: the impact of economic and demographic growth on the Antwerp City Council (1400-1550). UH 474 (2020) 589-609.

617 FELKER-KANTOR M, Liberal law-and-order: the politics of police reform in Los Angeles. JUH 465 (2020) 1026-49.

618 FÖLLMER M, Urban individuality and urban governance in twentieth-century Europe. In GUNN S \& HULME T eds, New approaches to governance and rule in urban Europe since 1500. Abingdon: Routledge 2020. 233-52.

619 FORD J D, Telling tales: maritime law in Aberdeen in the early sixteenth century. In ARMSTRONG J W \& FRANKOT E eds, Cultures of law in urban northern Europe: Scotland and its neighbours c. 1350 c. 1650. Abingdon: Routledge 2020. 20-36.

620 FRANKOT E, Legal business outside the courts: private and public houses as spaces of law in the fifteenth century. In ARMSTRONG J W \& FRANKOT E eds, Cultures of law in urban northern Europe: Scotland and its neighbours c. 1350 - c. 1650. Abingdon: Routledge 2020. 172-91.

621 FRENCH-MARCELIN M, Doing business New Orleans style: racial progressivism and the politics of uneven development. In DIAMOND A J \& SUGRUE T J eds, Neoliberal cities: the remaking of postwar urban America. New York: New York University Press 2020. 98-127.

622 GRAHAM A, Towns, government, legislation and the 'police' in Jamaica and the British Atlantic, 1770-1805. UH 471 (2020) 41-62.

623 GREENHALGH J, The new urban social history? Recent theses on urban development and governance in post-war Britain. UH 473 (2020) 535-45.

624 GUNN S \& HULME T, Introduction: unravelling urban governance. In GUNN S \& HULME T eds, New approaches to governance and rule in urban Europe since 1500. Abingdon: Routledge 2020. 1-22.

625 HÄBERLEIN M \& RAJKAY B, Politics under the Patrician regime, 1548-1806. In TLUSTY B A \& HÄBERLEIN M eds, A companion to late medieval and early modern Augsburg. Leiden: Brill 2020. 146-70.

626 HACKENBERGER B \& MILLER C, Watershed politics: groundwater management and resource conservation in Southern California's Pomona Valley. JUH 461 (2020) 50-62. 
627 HAVINGA A D, The vernacularisation of the Aberdeen Council Registers (1398-1511). In ARMSTRONG J W \& FRANKOT E eds, Cultures of law in urban northern Europe: Scotland and its neighbours c. 1350 - c. 1650. Abingdon: Routledge 2020. 78-101.

628 HEPBURN W \& SMALL G, Common books in Aberdeen, c. 1398 - c. 1511. In ARMSTRONG J W \& FRANKOT E eds, Cultures of law in urban northern Europe: Scotland and its neighbours c. 1350 - c. 1650. Abingdon: Routledge 2020. 37-54.

629 HIRSCHL R, City, state: constitutionalism and the megacity. Oxford: Oxford University Press 2020. pp 224.

630 JAFFE J, The Indian panchayat, access to knowledge and criminal prosecutions in colonial Bombay, 1827-61. L \& HR 381 (2020) 47-74.

631 KOENIG A M, Shipping fools: Foucault's wandering madman and civic responsibility in late medieval Germany. JSocH 541 (2020) 125-60.

632 KREUTZ P, Civil law. In TLUSTY B A \& HÄBERLEIN M eds, A companion to late medieval and early modern Augsburg. Leiden: Brill 2020. 196-217.

633 KYUNG LEE M, The bureaucracy of plans: urban governance and maps in nineteenth-century Paris. JUH 462 (2020) 248-69.

634 LAGRAND J B, Understanding urban progressivism and the City Beautiful movement. PH 871 (2020) 11-21.

635 LOSIER T, 'The public does not believe the police can police themselves': the mayoral administration of Harold Washington and the problem of policy impunity. JUH 465 (2020) 1050-65.

636 MCCLENDON M C, Women, the courts, and urban government in early reformation Norwich. EMW 142 (2020) 79-100.

637 MCGOVERN J, The sheriffs of York and Yorkshire in the Tudor period. NH 571 (2020) 60-76.

638 MOTZAFI-HALLER D, Patronage and development in the Israeli Negev: Yeruham, 1952-1953. MES 562 (2020) 290-304.

639 NAIR J, Modernity and 'publicness': the career of the Mysore matha, 1880-1940. IESHR 571 (2020) $5-29$.

640 PAUL J, Balkh, from the Seljuqs to the Mongal invasion. In DURAND-GUÉDY D, MOTTAHEDEH R \& PAUL J eds, Cities of medieval Iran. Leiden: Brill 2020. 313-51.

641 PHILLIPS C B \& RIGBY S H, The incorporation of Kendal in 1575. NH 571 (2020) 43-59.

642 ROGGE J, Pax urbana. The use of law for the achievement of political goals. In ARMSTRONG J W \& FRANKOT E eds, Cultures of law in urban northern Europe: Scotland and its neighbours c. 1350 - c. 1650. Abingdon: Routledge 2020. 138-53.

643 ROSE M \& BILES R, Arthur Rubloff and the grinding politics of renewal in Chicago, 1947 to 1986. JUH 466 (2020) 1341-67.

644 SAUMAREZ SMITH O, Action for cities: the Thatcher government and inner-city policy. UH 472 (2020) 274-91.

645 SEVILLA-BUITRAGO A, 'A community not our own': urban enclosure and spatial governmentality under fascism. In GUNN S \& HULME T eds, New approaches to governance and rule in urban Europe since 1500. Abingdon: Routledge 2020. 211-32.

646 SIMPSON A R C, Andrew Alanson: man of law in the Aberdeen Council register, c. 1440 - c. 1475 ? In ARMSTRONG J W \& FRANKOT E eds, Cultures of law in urban northern Europe: Scotland and its neighbours c. $1350-$ c. 1650. Abingdon: Routledge 2020. 247-67. 
647 TACOMA L E, Roman political culture: seven studies of the senate and city councils of Italy from the first to the sixth century AD. Oxford: Oxford University Press 2020. pp 336.

648 TVEIT M, Urban law in Norwegian market towns: legal culture in a long fourteenth century. In ARMSTRONG J W \& FRANKOT E eds, Cultures of law in urban northern Europe: Scotland and its neighbours c. $1350-$ c. 1650 . Abingdon: Routledge 2020. 102-20.

649 WEISS S, The 'Dravert Affair': paperwork and the administration of negligent street maintenance in modern Paris. JUH 462 (2020) 289-309.

650 WILSON A L M, Notaries and advocates in early modern Aberdeen. In ARMSTRONG J W \& FRANKOT E eds, Cultures of law in urban northern Europe: Scotland and its neighbours c. 1350 c. 1650. Abingdon: Routledge 2020. 268-85.

651 WISHNITZER A, Kerosene nights: light and enlightenment in late Ottoman Jerusalem. $P$ \& $P 2481$ (2020) 165-207.

652 WUBS-MROZEWICZ J, Conflicts about property: ships and inheritance in Danzig and in the Hanse area (fifteenth to sixteenth centuries). In ARMSTRONG J W \& FRANKOT E eds, Cultures of law in urban northern Europe: Scotland and its neighbours c. 1350 - c. 1650. Abingdon: Routledge 2020. 192-207.

$653 \mathrm{XU}$ C, Imperialism in the city: war and the making of the municipal administration in the French Concession of Shanghai in the Taiping period, 1853-1862. UH 471 (2020) 126-51.

654 ZAKRZEWSKI D, Local elites and dynastic succession: Tabriz prior to, under and following Mongol rule (sixth/twelfth to ninth/fifteenth centuries). In DURAND-GUÉDY D, MOTTAHEDEH R \& PAUL J eds, Cities of medieval Iran. Leiden: Brill 2020. 352-94.

655 ZÉPHIRIN R, Political demography and urban governance in French Guyana: implications for Latin America and the Caribbean. London: Palgrave Macmillan 2020. pp xiii +106.

\section{Political activism}

656 BAJRANGE D, GANDEE S \& GOULD W, Settling the citizen, settling the nomad: 'habitual offenders', rebellion, and civic consciousness in western India, 1938-1952. MAsS 542 (2020) 337-83.

657 BENWELL M C, DAVIES A, EVANS B \& WILKINSON C, Engaging political histories of urban uprisings with young people: the Liverpool riots, 1981 and 2011. EPC 384 (2020) 599-618.

658 BETTI E, Conceiving the atomic bomb threat between west and east: mobilisation, representation and perception against the A-bomb in 1950s Red Bologna. In BROOK R, DODGE M \& HOGG J eds, Cold War cities: politics, culture and atomic urbanism, 1945-1965. Abingdon: Routledge 2020. 252-77.

659 BLAIR M, 'Babies needn't follow': birth control and abortion policy and activism at the University of Waterloo and Waterloo Lutheran University, 1965-74. CBMH 371 (2020) 88-118.

660 BROWN G, 'Burn it down!': materialising intersectional solidarities in the architecture of the South African Embassy during the London Poll Tax Riot, March 1990. EPC 382 (2020) 233-50.

661 FARRAR M, HøGSBJERG C, LAVENDER L, MCGRATH M, PERRIGO S \& STEELE T, 'Paris today, Leeds tomorrow!' Remembering 1968 in Leeds. NH 572 (2020) 291-317.

662 GELLMAN E S, Troublemakers: Chicago freedom struggles through the lens of Art Shay. Chicago: University of Chicago Press 2020. pp 304.

663 GRIFFITHS S \& NAVICKAS K, The micro-geography of political meeting places in Manchester and Sheffield c. 1780-1850. In CLEMENTE A, LINDSTRÖM D \& STOBART J eds, Micro-geographies of the western city, c. 1750-1900. Abingdon: Routledge 2020. 183-205.

664 GRONNINGSATER S L H, Practicing formal politics without the vote: black New Yorkers in the aftermath of 1821. In GOSSE V \& WALDSTREICHER D eds, Revolutions and reconstructions: black politics in the long nineteenth century. Philadelphia: University of Pennsylvania Press 2020. 116-38. 
665 HARVEY K, Urban space, public protest, and nuclear weapons in early Cold War Sydney. In BROOK R, DODGE M \& HOGG J eds, Cold War cities: politics, culture and atomic urbanism, 1945-1965. Abingdon: Routledge 2020. 213-30.

666 HAVERTY D, Post-Bloody Sunday community politics in Derry's Bogside. Hire 281 (2020) 50-3.

667 HERMAN A C, Fascists at the fair: political resistance at the 1933-1934 Chicago World's Fair. JHS 33 2 (2020) 198-215.

668 HYLAND JR S, A sacred duty: nationalist and anti-imperialist activisms in Buenos Aires, 1916-1930. JUH 466 (2020) 1317-40.

669 JUDSON S, 'We're walking proud and talking loud because we're the new black Joes!': community leadership and tenants rights in Asheville's 1968 rent strike. JUH 464 (2020) 816-35.

670 KIRKLAND R, 'A secret, melodramatic sort of conspiracy': the disreputable legacies of Fenian violence in nineteenth-century London. $L J 451$ (2020) 39-52.

671 KUHN D P, The Hardhat Riot: Nixon, New York City, and the dawn of the white working-class revolution. Oxford: Oxford University Press 2020. pp 320.

672 LAAMANEN V, From communist cadre to outsider: ideals, opportunism, and coping with change in Moscow and Stockholm, 1929-1948. SJH 453 (2020) 334-59.

673 LAMBERT B, Citizenry and nationality: the participation of immigrants in urban politics in later medieval England. HWJ 901 (2020) 52-73.

674 LEGG S, 'Political atmospherics': the India Round Table Conference's atmospheric environments, bodies and representations, London 1930-1932. AAAG 1103 (2020) 774-92.

675 MASSEY C, The Labour Party's inquiry into Liverpool District Labour Party and expulsion of nine members of the Militant Tendency, 1985-1986. CBH 342 (2020) 299-324.

676 NUTTALL P, 'Whiteballed': Randolph Churchill, the Conservative Union and the Liverpool Conservative Party, 1935. NH 572 (2020) 250-69.

677 PANTER S, The place of port cities in self-narratives of German-speaking forty-eighters. In REIMANN C \& ÖHMANN M eds, Migrants and the making of the urban-maritime world: agency and mobility in port cities, c. 1570-1940. Abingdon: Routledge 2020. 227-50.

678 PATEY-FERGUSON P, LIFT and the GLC versus Thatcher: London's cultural battleground in 1981. NTQ 361 (2020) 4-16.

679 PHILP M, Radical conduct: politics, sociability and equality in London 1789-1815. Cambridge: Cambridge University Press 2020. pp 287.

680 PINARBASI S, Manchester antislavery, 1792-1807. SaA 412 (2020) 349-76.

681 PIXOVÁ M, Contested Czech cities: from urban grassroots to pro-democratic populism. London: Palgrave Macmillan 2020. pp xvii +186.

682 RYZOVA L, The battle of Muhammad Mahmoud Street in Cairo: the politics and poetics of urban violence in revolutionary time. $P$ \& $P 2471$ (2020) 273-317.

683 SCULL M M, 'They are murderers': the English Catholic Church and the Provisional IRA attacks on London. LJ 451 (2020) 65-85.

684 SMYLIE P, Communism in Cold War Belfast. LHR 851 (2020) 59-83.

685 STOUT J, The Popular Front and the Barcelona 1936 popular Olympics: playing as if the world was watching. London: Palgrave Macmillan 2020. pp xxi +136. 
686 SWYNGEDOUW E, The political art of urban insurgency. In LOUKAKI A ed, Urban art and the city: creating, destroying, and reclaiming the sublime. Abingdon: Routledge 2020. 120-31.

687 TOMLINSON J, Churchill's defeat in Dundee, 1922, and the decline of liberal political economy. HJ 624 (2020) 980-1006.

688 WALKER R, Deeds, not words: the Suffragettes and early terrorism in the City of London. LJ 451 (2020) 53-64.

689 WINSLOW C, Radical Seattle: the general strike of 1919. New York: Monthly Review Press 2020. pp 288.

\section{Shaping the urban environment Town planning (and environmental control)}

690 ABBOTT C, City planning: a very short introduction. Oxford: Oxford University Press 2020. pp 160.

691 ABRAMOVICH T, EPSTEIN-PLIOUCHTCH M \& ARAVOT I, Imported modernity and local design: the creation of resilient public spaces in late Ottoman Palestine, 1878-1918. PlP 351 (2020) $169-92$.

692 ALIVERNINI S, 'Let's move the earth and build a canal!' The management of water infrastructures in a Sumerian city at the end of the third millennium. WH 121 (2020) 93-104.

693 ALON-MOZES T \& GILAD-ILSAR S, Modern park for a modern city: planning Tel Aviv's Yarkon Park during the 1960s-1970s. SHGD 401 (2020) 80-94.

694 AMHOFF T, The agency of the paper plan: the building plans of late nineteenth-century and early twentieth-century Berlin. JUH 462 (2020) 270-88.

695 ANG I, Chinatowns and the rise of China. MAsS 544 (2020) 1367-93.

696 BARKE M, MOWL G \& SHIELDS G, 'Málaga Moderna': suburban development in late nineteenth and early twentieth century Andalucía. IJRLH 152 (2020) 89-110.

697 BECKETT J, Public parks and urban development during the nineteenth and twentieth centuries in Nottingham. MidH 451 (2020) 75-94.

698 BÉKÉSI S, The beginnings of the 'city machine': infrastructure expansion and international technology transfer in Vienna, 1850-1875. In ASH M G ed, Science in the metropolis: Vienna in transnational context, 1848-1918. Abingdon: Routledge 2020. 63-86.

699 BELOTO G E, Regional cities: international references in Brazilian regional planning in the 1950s and 1960s. PlP 353 (2020) 457-76.

700 BERNSTOCK P, Evaluating the contribution of planning gain to an inclusive housing legacy: a case study of London 2012. PlP 356 (2020) 927-53.

701 BOIFAVA B, The fourth nature of the contemporary city: from Rio de Janeiro to Seattle, Washington. SHGD 402 (2020) 128-45.

702 BONURA S E, Empire builder: John D. Spreckels and the making of San Diego. Lincoln, NE: University of Nebraska Press 2020. pp 440.

703 BORLAND J, Earthquake children: building resilience from the ruins of Tokyo. Cambridge MA: Harvard University Press 2020. pp 52.

704 BORLAND J, Small parks, big designs: reconstructed Tokyo's new green spaces, 1923-1931. UH 471 (2020) 106-25.

705 BROOK R, DODGE M \& HOGG J, Cold War cities: spatial planning, social and political processes, and cultural practices in the age of atomic urbanism, 1945-1965. In BROOK R, DODGE M 
\& HOGG J eds, Cold War cities: politics, culture and atomic urbanism, 1945-1965. Abingdon: Routledge 2020. 1-34.

706 BUTLER R J, Catholic power and the Irish city: modernity, religion, and planning in Galway, 19441949. JBS 593 (2020) 521-54.

707 CARUSO V, Suburban environment: East Naples historical transformations and sustainability. GE 13 2 (2020) 338-67.

708 CLARKE B, The city of Bristol: ground zero in the making. In BROOK R, DODGE M \& HOGG J eds, Cold War cities: politics, culture and atomic urbanism, 1945-1965. Abingdon: Routledge 2020. 54-66.

709 COLLINS M P, The preparation of town planning schemes in the Metropolitan Police District, excluding the county of London, 1909-1934. PlP 351 (2020) 1-26.

710 COOK M, 'Shaken but not stirred': the aftermath of urban disasters. In MCKINNON S \& COOK M eds, Disasters in Australia and New Zealand: historical approaches to understanding catastrophe. London: Palgrave Macmillan 2020. 79-98.

711 CRAPPER M, The valens aqueduct of Constantinople: hydrology and hydraulics. WH 124 (2020) $427-48$.

712 DENOYELLES A, 'Letting in the light': Jacob Riis's crusade for breathing spaces on the Lower East Side. JUH 464 (2020) 775-93.

713 DOBBIE M, MORGAN R \& FROST L, Overcoming abundance: social capital and managing floods in inner Melbourne during the nineteenth century. JUH 461 (2020) 33-49.

714 DOBBIE M, MORGAN R \& FROST L, Trees, wood, and paper: materialities of urban arboriculture in modern Berlin. JUH 462 (2020) 310-33.

715 DOCKERILL B \& STURZAKER J, Green belts and urban containment: the Merseyside experience. PlP 354 (2020) 583-608.

716 DOSTALÍK J, The natural environment in socialist modernity: three case studies of new urban areas in Czechoslovakia (1966-1991). PlP 355 (2020) 895-907.

717 ELSPAS M \& STRANGE A, Friends of reform: the correspondence of J. Horace McFarland and Mira Lloyd Dock. PH 871 (2020) 122-8.

718 FENNELLY K, The institution and the city: the impact of hospitals and workhouses on the development of Dublin's north inner city, c. 1773-1911. UH 474 (2020) 671-88.

719 FILION P, Time scales and planning history: medium- and long-term interpretations of downtown Toronto planning and development. PlP 352 (2020) 345-69.

720 FOLLADOR D, DUARTE F \& CARRIER M, Institutional arrangements and political shifts in Curitiba, Brazil: a comparative analysis of the 2004 and 2014 master plans. JPH 192 (2020) 112-28.

721 FROST L, Water and the making of Californian and Australian cities: introduction. JUH 461 (2020) 3-14.

722 FROST L, Water technology and the urban environment: water, sewerage, and disease in San Francisco and Melbourne before 1920. JUH 461 (2020) 15-32.

723 GAYNOR A, Lawnscaping Perth: water supply, gardens, and scarcity, 1890-1925. JUH 461 (2020) 63-78.

724 GOODMAN A, Karl Linn and the foundations of community design: from progressive models to the war on poverty. JUH 464 (2020) 794-815.

725 GÓRNY K \& GÓRNA A, Street names in Dakar-Plateau: a colonial and post-colonial perspective. PlP 355 (2020) 849-72. 
726 GREGORY J, 'A spirit of Bolshevism?': Perth's water crisis of the 1920s. JUH 461 (2020) 79-97.

727 GUTMAN M, Introduction: making and unmaking neighborhood boundaries in postwar U.S. cities. JUH 466 (2020) 1191-205.

728 HARRIS R, The world's first slum improvement programme: Calcutta's bustees, 1876-1910. PlP 352 (2020) 321-44.

729 HEBBERT M, The long after-life of Christopher Wren's short-lived London plan of 1666. PlP 352 (2020) 231-52.

730 HENSLEY M, MATEO-BABIANO D, MINNERY J \& POJANI D, How diverging interests in public health and urban planning can lead to less healthy cities. JPH 192 (2020) 71-89.

731 HESS D B \& PAE T, Competing militarisation and urban development during the Cold War: how a Soviet air base came to dominate Tartu, Estonia. In BROOK R, DODGE M \& HOGG J eds, Cold War cities: politics, culture and atomic urbanism, 1945-1965. Abingdon: Routledge 2020. 140-59.

732 HØGHØJ M, Planning Aarhus as a welfare geography: urban modernism and the shaping of 'welfare subjects' in post-war Denmark. PlP 356 (2020) 1031-53.

733 IZADY M M R, Urban unplanning: how violence, walls, and segregation destroyed the urban fabric of Baghdad. JPH 191 (2020) 52-68.

734 KALB M, Water, sand, molluscs: imperial infrastructures, the age of hydrology, and German colonialism in Swakopmund, Southwest Africa, 1884-1915. EnvH 262 (2020) 175-206.

735 KLARIN T B, The exchange of urban planning theory and practice along the Austro-Hungarian periphery: Zagreb as a case study. In GANTNER E, HEIN-KIRCHER H \& HOCHADEL O eds, Interurban knowledge exchange in southern and eastern Europe, 1870-1950. Abingdon: Routledge 2020. 91-117.

736 KLEMUN M, Metropolitan geology and metropolitan collections: turning Vienna into stones in the nineteenth century. In ASH M G ed, Science in the metropolis: Vienna in transnational context, 1848-1918. Abingdon: Routledge 2020. 87-107.

737 KYUNG LEE M \& WEISS S, Introduction: cities on paper: on the materiality of paper in urban planning. JUH 462 (2020) 239-47.

738 LARSSON T, Policing Stockholm's filth: flow to fixedness, 1776-1836. In CLEMENTE A, LINDSTRÖM D \& STOBART J eds, Micro-geographies of the western city, c. 1750-1900. Abingdon: Routledge 2020. 127-43.

739 LAWREY A, The Warsaw metro and the Warsaw pact: from deep cover to cut-and-cover. In BROOK R, DODGE M \& HOGG J eds, Cold War cities: politics, culture and atomic urbanism, 1945-1965. Abingdon: Routledge 2020. 116-39.

740 LIU Y, DUPRE K, JIN X \& WEAVER D, Dalian's unique planning history and its contested heritage in urban regeneration. PlP 355 (2020) 873-94.

741 LIU Z, UYTTENHOVE P M K J, BEECKMANS L \& ZHENG X, Major events and urban development: exploring the spatial impact of China's expositions in the early twentieth century. PlP 355 (2020) 779-804.

742 LIZARZABURU J, The Surco canal, an ancient irrigation canal in Lima, Peru, and a citizens' campaign for its protection. WH 123 (2020) 299-310.

743 LLOYD R, WHITE P \& BRENNAN C, Escaping water: living against floods in Townsville, North Queensland, from settlement to 2019. In MCKINNON S \& COOK M eds, Disasters in Australia and New Zealand: historical approaches to understanding catastrophe. London: Palgrave Macmillan 2020. 99-117.

744 LOIR C \& SCHLESSER T, The gap between large-scale planning and the building-scale in the eighteenth and nineteenth centuries (Brussels-Paris). In CLEMENTE A, LINDSTRÖM D \& STOBART J eds, 
Micro-geographies of the western city, c. 1750-1900. Abingdon: Routledge 2020. 87-105.

745 LONERGAN G \& KUKUSHKIN K, The foundation of St Petersburg as a variation upon Foucault's governmentality: the Russian service city, 1703-1740. In GUNN S \& HULME T eds, New approaches to governance and rule in urban Europe since 1500. Abingdon: Routledge 2020. 169-88.

746 LOUGHRAN K, Urban parks and urban problems: an historical perspective on green space development as a cultural fix. US 5711 (2020) 2321-38.

747 MCCLURE J R, 'Charms which no other ground possesses': Wildwood Park in Harrisburg's City Beautiful movement. PH 871 (2020) 129-35.

748 MACKINTOSH P G, Liberalism underfoot: a micro-geography of street paving and social dissolution - Brunswick Avenue, Toronto, Ontario, 1898-1899. In CLEMENTE A, LINDSTRÖM D \& STOBART J eds, Micro-geographies of the western city, c. 1750-1900. Abingdon: Routledge 2020. 106-26.

749 MCTOMINEY A, A tale of two Yorkshire villages: the local environmental impact of British reservoir development, c. 1866-1966. EnvH 263 (2020) 331-58.

750 MCTOMINEY A, Water and the modern engineered city: the Association of Water Engineers in a British and transnational context, 1896-1914. WH 122 (2020) 131-49.

751 MAROUFI $\mathrm{H}$, Urban planning in ancient cities of Iran: understanding the meaning of urban form in the Sasanian city of Ardašir-Xwarrah. PlP 356 (2020) 1055-80.

752 MEDRANO A D, The edible tide: how estuaries and migrants transformed the Straits of Melaka, 1870-1940. JSeAS 514 (2020) 579-96.

753 MINNER J \& ABBOTT M, Conservation logics that reshape mega-event spaces: San Antonio and Brisbane post expo. PlP 355 (2020) 753-77.

754 MOGA S T, Urban lowlands: a history of neighborhoods, poverty, and planning. Chicago: University of Chicago Press 2020. pp 240.

755 MORAVČÍKOVÁ H, PASTOREKOVÁ L \& LOVRA E, Antal Palóczi and the beginnings of modern urban planning in the kingdom of Hungary: the example of Bratislava and Novi Sad (1867-1918). PlP 352 (2020) 371-81.

756 MORGAN R, The allure of climate and water independence: desalination projects in Perth and San Diego. JUH 461 (2020) 113-28.

757 MORGANTE M, In the middle of the atomic arena: visible and invisible NATO sites in Verona during the fifties. In BROOK R, DODGE M \& HOGG J eds, Cold War cities: politics, culture and atomic urbanism, 1945-1965. Abingdon: Routledge 2020. 231-51.

758 NADAL I, PIQUÉ F \& NOBAJAS A, Cartography and urban planning: the city plan of Barcelona by Miquel Garriga i Roca (1856-1862). IM 721 (2020) 1-13.

759 NOIZET H, Spaces and spatialities in Paris between the ninth and nineteenth centuries: urban morphology generated by the management of otherness. UH 473 (2020) 401-20.

760 NOVO P A \& ZARRAGA K, Uses and users of water in Bilbao, c. 1890-1910: a socio-spatial analysis. UH 471 (2020) 86-105.

761 O'HANLON S \& SPEARRITT P, From water engineers to financial engineering: water provision in Australia's East Coast capital cities, 1945-2015. JUH 461 (2020) 98-112.

762 OZDIL N C, VEJRE H \& BILSEL F C, Emergence and evolution of the urban public open spaces of Ankara within the urban development history: 1923 to present. JPH 191 (2020) 26-51.

763 PATTILLO M, Race, poverty, and neighborhood planning in Chicago from the New Deal to neoliberalism. In DIAMOND A J \& SUGRUE T J eds, Neoliberal cities: the remaking of postwar urban 
America. New York: New York University Press 2020. 13-48.

764 PAULSSON A, The city that the metro system built: urban transformations and modalities of integrated planning in Stockholm. US 5714 (2020) 2936-55.

765 PETTEGREW D \& LAGRAND J B, Harrisburg, the City Beautiful: recasting the history of urban reform in a small American capital. PH 871 (2020) 1-10.

766 PINEDA V S, Building the inclusive city: governance, access, and the urban transformation of Dubai. London: Palgrave Macmillan 2020. pp xvii +169 .

767 PORTNOÏ A, Shankland and Cox at Cergy-Pontoise. Passing on British town planning working practices in France. PlP 353 (2020) 525-47.

768 PUHMAJER P, The urban expansion of Rijeka as a reflection of the city's multi-ethnic society. In FOLIN M \& PORFYRIOU H eds, Controversial heritage and divided memories from the nineteenth through the twentieth centuries. Abingdon: Routledge 2020. 95-106.

769 RAMESH A \& RAVEENDRANATHAN V, Infrastructure and public works in colonial India: towards a conceptual history. HC 186 (2020) 1-10.

770 RANTE R, Iranian cities: settlements and water management from antiquity to the Islamic period. In DURAND-GUÉDY D, MOTTAHEDEH R \& PAUL J eds, Cities of medieval Iran. Leiden: Brill 2020. 39-76.

771 REAVEN M, Neighborhood activism in planning in New York City, 1945-1975. JUH 466 (2020) 1261-89.

772 RIMBY S, Mira Lloyd Dock and the City Beautiful campaign. PH 871 (2020) 108-12.

773 SARVIS A, Mapping urban change in Harrisburg, 1900-1930. PH 871 (2020) 45-65.

774 SCHIFANI A M, Urban ecology and intervention in the 21st century Americas: verticality, catastrophe, and the mediated city. Abingdon: Routledge 2020. pp 150.

775 SCHLEY D, Steam city: railroads, urban space, and corporate capitalism in nineteenth-century Baltimore. Chicago: University of Chicago Press 2020. pp 352.

776 SCHMIDT S, Nuclear anxiety in postwar Japan's city of the future. In BROOK R, DODGE M \& HOGG J eds, Cold War cities: politics, culture and atomic urbanism, 1945-1965. Abingdon: Routledge 2020. 89-107.

777 SEDIGHI M \& MOTA N, Kuy-e Narmark (1952-1958): the growth and change of an urban community in Tehran. PlP 353 (2020) 477-504.

778 SHELEKPAYEV N, Whose master plan? Kisho Kurokawa and 'capital planning' in post-Soviet Astana, 1995-2000. PlP 353 (2020) 505-23.

779 SHEN J \& XIAO Y, Emerging divided cities in China: socioeconomic segregation in Shanghai, 20002010. US 576 (2020) 1338-56.

780 SHOSH ROTEM S, Tel-Aviv and the sea: models of inspiration. JTH 122 (2020) 156-72.

781 SINGER M F, Bellevue Park: the suburb beautiful and enduring. PH 871 (2020) 136-47.

782 SPACKMAN C, Just noticeable: erasing place in municipal water treatment in the U.S. during the interwar period. JHG 671 (2020) 2-13.

783 STIEFEL B L, A case study of automotive development in the emerging city of Barcelona, c. 19001950. In GANTNER E, HEIN-KIRCHER H \& HOCHADEL O eds, Interurban knowledge exchange in southern and eastern Europe, 1870-1950. Abingdon: Routledge 2020. 230-54.

784 STOCK J L \& CHUSID J M, Urbanizing India’s frontier: Sriganganagar and canal-town planning on the Indus plains. PlP 352 (2020) 253-76. 
785 SULTSON S, Towards a prosperous future through Cold War planning: Stalinist urban design in the industrial towns of Sillamäe and Kohtla-Järve, Estonia. In BROOK R, DODGE M \& HOGG J eds, Cold War cities: politics, culture and atomic urbanism, 1945-1965. Abingdon: Routledge 2020. 67-87.

786 SUN W, Public space in Chinese urban design theory after 1978: a compressed transculturation. JA 251 (2020) 65-76.

787 SWAYAMPRAKASH R, Flotsam: garbage dumping, pollution, and legal tensions in the Detroit River. WH 123 (2020) 361-71.

788 TAYLOR E J, The 'desiccator difficulty': surprise, indignation and the local politics of planning for sanitary technology in nineteenth century Melbourne. PlP 353 (2020) 433-55.

789 TEWDWR-JONES M, SOOKHOO D \& FREESTONE R, From Geddes' city museum to Farrell's urban room: past, present, and future at the Newcastle City Futures exhibition. PlP 352 (2020) 277-97.

790 TOZOGLU A E, The new visual culture in eighteenth-century Istanbul: building up new shore kiosks and gardens on the outskirts of the royal palace. MES 562 (2020) 165-92.

791 UCEDA A C \& TERÉS A S, A city made of rooms. Revisiting the interactions between urban planning and building typology in Mario Ridolfi's projects for Terni. PlP 354 (2020) 635-55.

792 VALLYE A, 'Balance-sheet' city: Martin Wagner and the visualization of statistical data. JUH 462 (2020) 334-63.

793 VERLAAN T, The neues Kreuzberger Zentrum: urban planners, property developers and fractious left politics in West Berlin, 1963-1974. GeH 381 (2020) 113-32.

794 VITALE P, Properties of science: how industrial research and the suburbs reshaped each other in Cold War Pittsburgh. In BROOK R, DODGE M \& HOGG J eds, Cold War cities: politics, culture and atomic urbanism, 1945-1965. Abingdon: Routledge 2020. 35-53.

795 VITIELLO D \& BLICKENDERFER Z, The planned destruction of Chinatowns in the United States and Canada since c. 1900. PlP 351 (2020) 143-68.

796 WAGNER P, Urban planning and the politics of expert internationalism, 1920s-1940s. JWH 311 (2020) 79-110.

797 WILKOF S, An 'ordinary modernist'? Empire and nation in Ariel Kahane's large-scale planning. PlP 355 (2020) 805-26.

798 WILLIAMSON F, Responding to extremes: managing urban water scarcity in the late nineteenthcentury Straits Settlements. WH 123 (2020) 251-63.

799 YEE D, The making of Mexico City's historic center: national patrimony in the age of urban renewal. JPH 192 (2020) 90-111.

800 ŽIVKOVIĆ V, Sacral topography, charity and hospitals in late medieval Kotor. In CRAWSHAW J L S, LATIN I B \& VONGSATHORN K eds, Tracing hospital boundaries: integration and segregation in southeastern Europe and beyond, 1050-1970. Leiden: Brill 2020. 193-212.

\section{Urban renewal}

801 AMMON F R, Reversing the tide of suburban families? The design, marketing, and occupancy of urban renewal's high-rise housing. JPH 194 (2020) 228-55.

802 APPLER D R \& RIESENWEBER J, Urban renewal through the lens of unsuccessful projects: the Pralltown neighborhood of Lexington, Kentucky. JPH 193 (2020) 164-86.

803 DESENA J N \& KRASE J, Brooklyn revisited: an illustrated view from the street 1970 to the present. In KRASE J \& DESANA J N eds, Gentrification around the world, vol. I: Gentrifiers and the displaced. London: Palgrave Macmillan 2020. 13-35. 
804 DIAMOND A J \& SUGRUE T J, Introduction: historicizing the neoliberal metropolis. In DIAMOND A J \& SUGRUE T J eds, Neoliberal cities: the remaking of postwar urban America. New York: New York University Press 2020. 1-12.

805 EOM S, Infrastructures of displacement: the transpacific travel of urban renewal during the Cold War. PlP 352 (2020) 299-319.

806 FAIRBANKS R B, Federal urban renewal in three small Texas cities: a mixed legacy. JPH 193 (2020) 187-203.

807 HADJILAH A \& CHÉRIF N, The casbah of Algiers's transformation between 1833 and 1859: expropriation, concession, and plot remodeling. JUH 464 (2020) 889-907.

808 HOCHFELDER D \& APPLER D, Introduction to special issue on urban renewal in smaller cities. JPH 193 (2020) 139-43.

809 KAHLER S \& HARRISON C, 'Wipe out of the entire slum area': university-led urban renewal in Columbia, South Carolina, 1950-1985. JHG 671 (2020) 61-70.

810 KAYA E, Transformation of Sydney's industrial historic waterfront: the production of tourism for consumption. London: Palgrave Macmillan 2020. pp xiv +218 .

811 KINSELLA C, Urban regeneration and neoliberalism: the new Liverpool home. Abingdon: Routledge 2020. pp 238.

812 KONOVE A, Making a modern barrio: infrastructure and progress in Mexico City, 1900-1903. JUH 463 (2020) 516-40.

813 LYMAN I \& KONSTANTINOVA V, In search of best practices within the confines of the Russian empire: the port city of Berdyansk. In GANTNER E, HEIN-KIRCHER H \& HOCHADEL O eds, Interurban knowledge exchange in southern and eastern Europe, 1870-1950. Abingdon: Routledge 2020. 49-74.

814 MCWILLIAM R, London's West End: creating the pleasure district, 1800-1914. Oxford: Oxford University Press 2020. pp 400.

815 PEARLMAN L, The bicentennial and the battle over DC's downtown redevelopment during the 1970s. JPH 194 (2020) 207-27.

816 PFAU A \& SEWELL S K, Newburgh's 'last chance': the elusive promise of urban renewal in a small and divided city. JPH 193 (2020) 144-63.

817 POOLE L A R \& APPLER D R, Building a local preservation ethic in the era of urban renewal: how did neighborhood associations shape historic preservation practice in Lexington, Kentucky? JUH 462 (2020) 383-405.

818 RETZLAFF R, Connecting public school segregation with urban renewal and interstate highway planning: the case of Birmingham, Alabama. JPH 194 (2020) 256-80.

819 ROMANO G C, Changing urban renewal policies in China: policy transfer and policy learning under multiple hierarchies. London: Palgrave Macmillan 2020. pp xvii +245.

820 WEE H K, The emergence of the global and social city: Golden Mile and the politics of urban renewal. PlP 354 (2020) 689-718.

821 WILLIAMS H, Fortifying the city: visualising London 2012. LJ 451 (2020) 106-22.

822 YAO Z \& JIANG C, Imitation, reference, and exploration - development path to urban renewal in China (1985-2017). JUH 464 (2020) 728-46. 


\section{Urban culture \\ Urban renewal}

823 CHATTERJI T \& ROY S, Gentrification and post-industrial spatial restructuring in Calcutta, India. In KRASE J \& DESANA J N eds, Gentrification around the world, vol. II: Innovative approaches. London: Palgrave Macmillan 2020. 269-88.

824 DI VIRGILIO M M, Gentrification processes in the city of Buenos Aires: new features and old tendencies. In KRASE J \& DESANA J N eds, Gentrification around the world, vol. II: Innovative approaches. London: Palgrave Macmillan 2020. 243-65.

825 KOSTRZEWA A, New business in the old neighbourhood: young Polish shopkeepers' responses to commercial gentrification in Greenpoint, Brooklyn. In KRASE J \& DESANA J N eds, Gentrification around the world, vol. II: Innovative approaches. London: Palgrave Macmillan 2020. 37-62.

826 LILIUS J, MyyrYork: rejuvenating a housing estate neighborhood for the next generation of residents. In KRASE J \& DESANA J N eds, Gentrification around the world, vol. II: Innovative approaches. London: Palgrave Macmillan 2020. 159-86.

827 MENDES L F G, Anti-displacement social movements in Lisbon: a perspective from the trenches in the fight against transnational gentrification. In KRASE J \& DESANA J N eds, Gentrification around the world, vol. II: Innovative approaches. London: Palgrave Macmillan 2020. 107-29.

828 MÜLLAUER-SEICHTER W, Tools for citizen participation in segmented societies: the case of Barranco. In KRASE J \& DESANA J N eds, Gentrification around the world, vol. II: Innovative approaches. London: Palgrave Macmillan 2020. 219-42.

829 RODRÍGUEZ-BARCÓN A, CALO E \& OTERO-ENRÍQUEZ R, Social transformation and urban regeneration: three interpretations on the phenomenon of gentrification in the historic center of $\mathrm{A}$ Coruña (Spain). In KRASE J \& DESANA J N eds, Gentrification around the world, vol. II: Innovative approaches. London: Palgrave Macmillan 2020. 65-82.

830 SHEARER S, Revanchist Kigali: retro-Victorian urbanism and the gentrification of a twenty-first-century metropolis. In KRASE J \& DESANA J N eds, Gentrification around the world, vol. II: Innovative approaches. London: Palgrave Macmillan 2020. 189-217.

831 SHORTELL T, The politics of visibility: gentrification and immigration in East London. In KRASE J \& DESANA J N eds, Gentrification around the world, vol. II: Innovative approaches. London: Palgrave Macmillan 2020. 131-57.

832 TISSOT S, Is gentrification the result of neoliberalism? The cultural making of the real estate market in Boston's South End, 1965-2005. In DIAMOND A J \& SUGRUE T J eds, Neoliberal cities: the remaking of postwar urban America. New York: New York University Press 2020. 154-72.

833 VAN AITKEN J \& BRAKE J, Shimmering surfaces, toxic atmospheres, incendiary miracles: public housing and the aesthetics of re-valorization in Salford UK. In KRASE J \& DESANA J N eds, Gentrification around the world, vol. II: Innovative approaches. London: Palgrave Macmillan 2020. 83-106.

\section{Urban culture and entertainment}

834 ACKERMANN D \& SARRAZANAS C, The abolition of the liturgical choregia and the creation of the agōnothesia in Athens: new considerations on a debated issue. JHelS 1401 (2020) 34-68.

835 ANDERSON B, Cities, mountains and being modern in fin-de-siècle England and Germany. London: Palgrave Macmillan 2020. pp xi +302 .

836 ANDREOZZI D, Cosmopolitan practices: lives, mercantilism and nations in the growth of multiethnic Trieste (18th-20th centuries). In FOLIN M \& PORFYRIOU H eds, Controversial heritage and divided memories from the nineteenth through the twentieth centuries. Abingdon: Routledge 2020. 81-94. 
837 BAKER S, NOWAK R, LONG P, COLLINS J \& CANTILLON Z, Community well-being, postindustrial music cities and the turn to popular music heritage. In BALLICO C \& WATSON A eds, Music cities: evaluating a global cultural policy concept. London: Palgrave Macmillan 2020. 43-61.

838 BEAMISH A, Rational entertainment and instructive amusement: Philadelphia's nineteenth-century urban pleasure gardens and the emergence of nightlife. SHGD 401 (2020) 14-42.

839 BENNETT T, Re-rewind: heritage, representation and music city aspiration in Southampton. In BALLICO C \& WATSON A eds, Music cities: evaluating a global cultural policy concept. London: Palgrave Macmillan 2020. 19-42.

840 BEVAN P, 'Intoxicating Shanghai' - an urban montage: art and literature in pictorial magazines during Shanghai's jazz age. Leiden: Brill 2020. pp xvi +421.

841 BROUN J L, Place, identity and social conflict in post-industrial England: cases from south Lincolnshire in the 1980s. CBH 343 (2020) 331-57.

842 BROWNE C L, The Leeds Mercury and the Leeds Intelligencer: reporting on the 'race of Factory Bills', 1833. NH 572 (2020) 198-215.

843 BUSCIGLIO-RITTER T, 'Coverable pictures': John Taylor Johnston (1820-1893), collecting art between New York and Europe. JHC 321 (2020) 73-90.

844 CARTER S \& GIBSON K, Amateur music-making among the mercantile community of Newcastle upon Tyne from the 1690s to the 1750s. In CARTER S, GIBSON K \& SOUTHEY R eds, Music in north-east England, 1500-1800. Woodbridge: Boydell \& Brewer 2020. 192-215.

845 CHEUNG S C H, Reflections on the historical construction of Huaiyang Cuisine: a study on the social development of Shanghai foodways in Hong Kong. GFH 62 (2020) 128-42.

846 CLEMENTS R \& FRANKCOM S, In conversation on the Royal Exchange Theatre, Manchester. NTQ 364 (2020) 369-83.

847 CORNISH C \& DRIVER F, 'Specimens distributed': the circulation of objects from Kew's Museum of Economic Botany, 1847-1914. JHC 322 (2020) 327-40.

848 CROSBIE B, Between the broadside ballad and the folksong: print and popular songs in eighteenthcentury Newcastle upon Tyne. In CARTER S, GIBSON K \& SOUTHEY R eds, Music in north-east England, 1500-1800. Woodbridge: Boydell \& Brewer 2020. 261-81.

849 DANN K, Enchanted New York: a journey along Broadway through Manhattan's magical past. New York: New York University Press 2020. pp 352.

850 DAUSER R, The dissemination of news, In TLUSTY B A \& HÄBERLEIN M eds, A companion to late medieval and early modern Augsburg. Leiden: Brill 2020. 391-414.

851 EICHNER B, Musical diplomacy in a divided city: the Lassus-Mayrhofer manuscripts. EMus 481 (2020) 55-74.

852 EMMERSON R, Circumnavigating the globe: RW Forsyth's Princes Street, and its meanings. BOEC $161(2020) 1-18$.

853 FAIETTI M, Francesco Francia (1450-1517) and printmaking in Renaissance Bologna. PQ 372 (2020) $176-7$.

854 FENTON R, NEAL L \& PATEY-FERGUSON P, Twenty-five years of LIFT: towards a plurality of positions. NTQ 361 (2020) 17-28.

855 FERRONE A, Stage business and the neoliberal theatre of London. London: Palgrave Macmillan 2020. pp vii +264 . 
856 FICERI O, The traitorous national periphery: the legacy of identity politics of imperial Hungary in a new eastern metropolis of Czechoslovakia - Košice/Kassa. EurRH 276 (2020) 824-46.

857 FISHER A J, Music. In TLUSTY B A \& HÄBERLEIN M eds, A companion to late medieval and early modern Augsburg. Leiden: Brill 2020. 553-74.

858 FLEMING S D I, Compositional activity in Durham City, 1750-1810: its influences and impact. In CARTER S, GIBSON K \& SOUTHEY R eds, Music in north-east England, 1500-1800. Woodbridge: Boydell \& Brewer 2020. 70-88.

859 FLOHR M, Urban space and urban history in the Roman world. Abingdon: Routledge 2020. pp 348.

860 FOLIN M \& MUSARRA A, Mediterranean cities as cultural crossroads: an introduction. In FOLIN M \& MUSARRA A eds, Cultures and practices of coexistence from the thirteenth through the seventeenth centuries: multi-ethnic cities in the Mediterranean world, vol. I. Abingdon: Routledge 2020. 1-8.

861 FONDARAS A, Augustinian art and meditation in Renaissance Florence. Leiden: Brill 2020. pp xiv + 370.

862 FORNASIERO A \& ZLATOHLÁVKOVÁ E, The studiolo of Rudolf II at Prague Castle. JHC 322 (2020) 239-44.

863 FUHRMANN M, Port cities of the eastern Mediterranean: urban culture in the late Ottoman Empire. Cambridge: Cambridge University Press 2020. pp 477.

864 GANTNER E, Traveling architecture: Géza Maróti's art between the regional and the global. In GANTNER E, HEIN-KIRCHER H \& HOCHADEL O eds, Interurban knowledge exchange in southern and eastern Europe, 1870-1950. Abingdon: Routledge 2020. 75-90.

865 GARDNER M, The selection, acquisition and performance of Handel's English odes and oratorios in mid-eighteenth-century Durham. In CARTER S, GIBSON K \& SOUTHEY R eds, Music in north-east England, 1500-1800. Woodbridge: Boydell \& Brewer 2020. 54-69.

866 GEMMILL E, Debt, distraint, display and dead men's treasure: material culture in late medieval Aberdeen. JMH 463 (2020) 350-72.

867 GROSVENOR I \& MYERS K, 'Dirt and the child': a textual and visual exploration of children's physical engagement with the urban and the natural world. HE 494 (2020) 517-35.

868 HALONEN M, Complex tools for complex time: solar, stellar, and lunar cycles of time in medieval Roman calendars. In HEIKKILÄ T ed, Time in the Eternal City: perceiving and controlling time in late medieval and Renaissance Rome. Leiden: Brill 2020. 275-314.

869 HEIKKILÄ T, Time and the Eternal City. In HEIKKILÄ T ed, Time in the Eternal City: perceiving and controlling time in late medieval and Renaissance Rome. Leiden: Brill 2020. 1-14.

870 HENG T, Of gods, gifts and ghosts: spiritual places in urban spaces. Abingdon: Routledge 2020. pp 248.

871 HOUSTON B, Rhythm, colour, and movements: narratives of art and life in black Pittsburgh. SaA 41 1 (2020) 64-78.

872 HUANG M Y-L, Collecting the new: major museum collections of twentieth-century Chinese painting in London and Oxford. MuHJ 132 (2020) 132-53.

873 IMMONEN V \& RÄSÄNEN E, From passion to bereavement: the Klaus Holma memorial collection at the Lahti City Museum, Finland. JHC 322 (2020) 379-90.

874 JENSON O C, 'Canny Newcassel': Marshall's musical metropolis of north Britain. In CARTER S, GIBSON K \& SOUTHEY R eds, Music in north-east England, 1500-1800. Woodbridge: Boydell \& Brewer 2020. 282-302. 
875 JONES M, The place of the Beatles within Liverpool as a UNESCO City of Music. In BALLICO C \& WATSON A eds, Music cities: evaluating a global cultural policy concept. London: Palgrave Macmillan 2020. 81-101.

876 KANTOLA U, Time set in stone: temporal references in the non-funerary epigraphy of Rome (10001527 ad). In HEIKKILÄ T ed, Time in the Eternal City: perceiving and controlling time in late medieval and Renaissance Rome. Leiden: Brill 2020. 106-58.

877 KAPURIA R, Of music and the Maharaja: gender, affect, and power in Ranjit Singh's Lahore. MAsS 542 (2020) 654-90.

878 KASSIK H, Calendars in use: comparing S. Pietro and S. Maria Maggiore in Rome. In HEIKKILÄ T ed, Time in the Eternal City: perceiving and controlling time in late medieval and Renaissance Rome. Leiden: Brill 2020. 242-74.

879 KASSIK H, Navigating the cycles of time: calendar dates and the week in a 13th-century Vatican calendar. In HEIKKILÄ T ed, Time in the Eternal City: perceiving and controlling time in late medieval and Renaissance Rome. Leiden: Brill 2020. 220-41.

880 KRYSSOVA E, 'Tales of wonder and horror': subject of insanity in the Leeds newspaper press miscellanies during the late Georgian era. NH 572 (2020) 215-28.

881 LADD B, The streets of Europe: the sights, sounds, and smells that shaped its great cities. Chicago: University of Chicago Press 2020. pp 320.

882 LAUBE M, 'The harmony of one choir'? Music and social unity in Reformation Heidelberg. $P$ \& $P$ 2481 (2020) 41-86.

883 MAHER S W, Film noir and Los Angeles: urban history and the dark imaginary. Abingdon: Routledge 2020. pp 218.

884 MARINI S A, From Newcastle upon Tyne to colonial Carolina: transatlantic tune transmission and Durham Hill's the Cashaway Psalmody (1770). In CARTER S, GIBSON K \& SOUTHEY R eds, Music in north-east England, 1500-1800. Woodbridge: Boydell \& Brewer 2020. 151-72.

885 MARSHALL A, Political journalism in London, 1695-1720: Defoe, Swift, Steele and their contemporaries. Woodbridge: Boydell \& Brewer 2020. pp 328.

886 MONRÓS-GASPAR L, A 'distinctive' map of London: women, theatre and the classics in 1893. NCTF 471 (2020) 26-42.

887 MONTANARI G, Politics, archaeology and passion for the antique in the 'cultural mediation' of Cyriac of Ancona between east and west. In FOLIN M \& MUSARRA A eds, Cultures and practices of coexistence from the thirteenth through the seventeenth centuries. Abingdon: Routledge 2020. 166-88.

888 MORRALL A, The arts. In TLUSTY B A \& HÄBERLEIN M eds, A companion to late medieval and early modern Augsburg. Leiden: Brill 2020. 495-525.

889 MOTTAHEDEH R P, Medieval lexicography on Arabic and Persian terms for city and countryside. In DURAND-GUÉDY D, MOTTAHEDEH R \& PAUL J eds, Cities of medieval Iran. Leiden: Brill 2020. 465-78.

890 MOURELATOS D, Depictions of the Virgin in an 11th-century hexaptych at Sinai as perception of the city of Constantinople. In LOUKAKI A ed, Urban art and the city: creating, destroying, and reclaiming the sublime. Abingdon: Routledge 2020. 90-103.

891 MOYER A E, The intellectual world of sixteenth-century Florence: humanists and culture in the age of Cosimo I. Cambridge: Cambridge University Press 2020. pp 401.

892 O'REILLY C, 'The magnetic pull of the metropolis': the Manchester Guardian, the provincial press and ideas of the north. NH 572 (2020) 270-90. 
893 PHILLIPS M, Making a 'free world' city: urban space and social order in Cold War Bangkok. In BROOK R, DODGE M \& HOGG J eds, Cold War cities: politics, culture and atomic urbanism, 19451965. Abingdon: Routledge 2020. 278-98.

894 PIHKO S, Temporal expressions in canonisation processes and diari, and the perception of time in late medieval Rome. In HEIKKILÄ T ed, Time in the Eternal City: perceiving and controlling time in late medieval and Renaissance Rome. Leiden: Brill 2020. 15-58.

895 PINCHERA V \& RINALLO D, The emergence of Italy as a fashion country: nation branding and collective meaning creation at Florence's fashion shows (1951-1965). BuH 621 (2020) 151-78.

896 POND K, 'A desire to look respectable in the eyes of strangers': the Victorian press and the figure of the stranger at the Great Exhibition of 1851. VPR 531 (2020) 57-75.

897 PROKOPOVYCH M, Governing taste: fin-de-siècle Cracow, its museums and the urban elite in the shaping of the modern metropolis. In GUNN S \& HULME T eds, New approaches to governance and rule in urban Europe since 1500. Abingdon: Routledge 2020. 64-84.

898 REK-WOŹNIAK M \& WOŹNIAK W, Working-class and memory policy in post-industrial cities: Łódź, Poland, and Tampere, Finland, compared. ILWCH 981 (2020) 5-21.

899 ROBB M E, Print and the Urdu public: Muslims, newspapers, and urban life in colonial India. Oxford: Oxford University Press 2020. pp 248.

900 ROBERTS C, 'I esteem my lot fortunate, in residing in this happy country': Edward Miller, social networking and music-making in eighteenth-century Doncaster. In CARTER S, GIBSON $\mathrm{K}$ \& SOUTHEY R eds, Music in north-east England, 1500-1800. Woodbridge: Boydell \& Brewer 2020. 89-108.

901 ROCK J, The Edinburgh Academy of St Luke at work, c. 1737-47. BOEC 161 (2020) 47-62.

902 RUBIN J E, New York klezmer in the early twentieth century. Woodbridge: Boydell \& Brewer 2020. pp 483.

903 RUBIN M, Cities of strangers: making lives in medieval Europe. Cambridge: Cambridge University Press 2020. pp 204.

904 SAVANT S B \& MAHDI M M, The history of Iranian cities through their books: what Ms. Köprülü 01589 tells us about 8th/14th century Shiraz. In DURAND-GUÉDY D, MOTTAHEDEH R \& PAUL J eds, Cities of medieval Iran. Leiden: Brill 2020. 430-64.

905 SCIREA F, Designing a visual language in Norman Sicily: the creation sequence in the mosaics of Palermo and Monreale. In WINKLER E A, FITZGERALD L \& SMALL A eds, Designing Norman Sicily: material culture and society. Woodbridge: Boydell \& Brewer 2020. 184-206.

906 SHENK L, Praising Elizabeth I in Latin at Norwich (1578). ERC 462 (2020) 83-110.

907 SITES W, Sun Ra's Chicago: Afrofuturism and the city. Chicago: University of Chicago Press 2020. pp 328.

908 STAMMERS T, The purchase of the past: collecting culture in post-revolutionary Paris c. 1790-1890. Cambridge: Cambridge University Press 2020. pp 375.

909 STOURAITI A, Marvels of the Levant: print media and the politics of wonder in early modern Venice. HWJ 901 (2020) 25-51.

910 SYGKELOS Y, Ottoman banal cosmopolitanism: Salonica at the end of Ottoman rule (1908-1912). In FOLIN M \& PORFYRIOU H eds, Controversial heritage and divided memories from the nineteenth through the twentieth centuries. Abingdon: Routledge 2020. 63-80.

911 TORELLO-HILL G \& TURNER A J, The Lyon Terence: its tradition and legacy. Leiden: Brill 2020. pp 310. 
912 TRONZO W, The interplay of media: textile, sculpture and mosaic. In WINKLER E A, FITZGERALD L \& SMALL A eds, Designing Norman Sicily: material culture and society. Woodbridge: Boydell \& Brewer 2020. 47-59.

913 VAHTIKARI T, Post-war urban pageants in Finland: performance, participation and power. In GUNN S \& HULME T eds, New approaches to governance and rule in urban Europe since 1500. Abingdon: Routledge 2020. 149-68.

914 VINZENT J, The making of modern art through commercial art galleries in 1930s London: the London Gallery (1936 to 1950). VCB 212 (2020) 145-76.

915 WARREN E, The York Antiphonal: history, liturgy and use in the late fifteenth century. In CARTER S, GIBSON K \& SOUTHEY R eds, Music in north-east England, 1500-1800. Woodbridge: Boydell \& Brewer 2020. 111-26.

916 WEBER W E J, Learned culture. In TLUSTY B A \& HÄBERLEIN M eds, A companion to late medieval and early modern Augsburg. Leiden: Brill 2020. 470-94.

917 WESTERMAN W, More than a mere footnote: the department of military studies, University of Sydney, 1907-1915. HE 491 (2020) 57-76.

918 WHITE E J, You talkin' to me? The unruly history of New York English. Oxford: Oxford University Press 2020. pp 216.

919 WILLIAMS R, History and memory of the Old Eighth Ward. PH 871 (2020) 164-78.

920 WILLIAMSON M, Recovering the soundscape of pre-Reformation Newcastle upon Tyne. In CARTER S, GIBSON K \& SOUTHEY R eds, Music in north-east England, 1500-1800. Woodbridge: Boydell \& Brewer 2020. 29-53.

921 WINKLER A E, Schoolboy performance in the post-Reformation north-east. In CARTER S, GIBSON K \& SOUTHEY R eds, Music in north-east England, 1500-1800. Woodbridge: Boydell \& Brewer 2020. 175-91.

922 WOOLLEY A, Tunes for violin or recorder collecting in north-east England and London in the late seventeenth century. In CARTER S, GIBSON K \& SOUTHEY R eds, Music in north-east England, 15001800. Woodbridge: Boydell \& Brewer 2020. 127-50.

923 WYATT D, Examining the evidence for Beverley as the late medieval and early modern centre for professional musicians in the north-east. In CARTER S, GIBSON K \& SOUTHEY R eds, Music in northeast England, 1500-1800. Woodbridge: Boydell \& Brewer 2020. 13-28.

\section{Exchange of information}

924 KARYDIS N, Discovering the Byzantine art of building: lectures at the RIBA, the Royal Academy and the London Architectural Society, 1843-58. ArchH 631 (2020) 171-90.

\section{Education}

925 AGNEW J, Creating new schools for Bradford's 'factory children': obstacles and outcomes, 18361850. NH 571 (2020) 120-41.

926 ASH M G, Metropolitan scientific infrastructures and spaces of knowledge in Vienna, 1848-1918. In ASH M G ed, Science in the metropolis: Vienna in transnational context, 1848-1918. Abingdon: Routledge 2020. 1-21.

927 BALLANTYNE T, Collecting, colonisation and civic culture in southern New Zealand. MuHJ 131 (2020) 42-60.

928 BRANTZ D, Metropolitan natural histories: inventing science, building cities, and displaying the world. In ASH M G ed, Science in the metropolis: Vienna in transnational context, 1848-1918. Abingdon: Routledge 2020. 22-40. 
929 CORNISH C, ALLAN P, GARDINER L, NICOL P, PARDOE H, SHERWOOD C, WEBSTER R, YOUNG D \& NESBITT M, Between metropole and province: circulating botany in British museums, 1870-1940. ANH 471 (2020) 124-46.

930 CRANE R, What were they thinking? Tracing evolution in the Otago Museum, 1868-1936. MuHJ 13 $1(2020) 61-79$.

931 DOWDALL A, War in the classroom: the materiality of educational spaces in the French front-line towns, 1914-1920. CulSH 175 (2020) 659-75.

932 GAIMSTER D, Fitting the colonial museum dashboard? Civic action, curatorial agency and identity building at the Auckland Museum (1852-1929). MuHJ 131 (2020) 80-94.

933 HAMILTON J, Building 'the palace of bokes': Robert Reid, William Stark and the Signet Library. BOEC 161 (2020) 77-92.

934 HERMAN F \& PRIEM K, Images of industrial life and vocational training: scouting as a liminal space for educating a workers' elite in 1920s Luxembourg. HE 494 (2020) 553-70.

935 HOLT P, Performing in a different place: the use of a prodigy to the Dublin Philosophical Society. BJHS 533 (2020) 371-88.

936 JENKINS B, Race before Darwin: variation, adaption and the natural history of man in post-Enlightenment Edinburgh, 1790-1835. BJHS 533 (2020) 333-50.

937 KIRWAN A, Sociability, radium and the maintenance of scientific culture and authority in twentiethcentury Ireland: a case study of the Royal Dublin Society. BJHS 531 (2020) 47-66.

938 LIPPERT A, The visual pedagogy of reform: picturing white slavery in America. JUH 464 (2020) $854-88$.

939 MACDIARMADA M, 'Those little ones immersed in a sea of foreign influences': teaching Irish language and culture to children in London in the early 1900s. IESH 471 (2020) 97-111.

940 MAYER C, The urban and the natural in education reform: the development of Hamburg Schullandheime (rural school hostels) in the 1920s. HE 494 (2020) 459-75.

941 MEASELL J S, Design education for industry: the impact of the Stourbridge School of Art upon the local glass enterprises, 1850-1905. MidH 453 (2020) 341-56.

942 MURCIA J P M \& RUIZ-FUNES J M, Froebel and the teaching of botany: the garden in the Kindergarten Model School of Madrid. PaedH 56 1-2 (2020) 200-16.

943 NEWMAN L \& DRIVER F, Kew Gardens and the emergence of the school museum in Britain, 18801930. HJ 625 (2020) 1204-30.

944 PENALOZA-PATZAK B, Capital collections, complex systems: Vienna, Berlin, and ethnographic specimen exchanges in transnational fin de siècle scientific networks. In ASH M G ed, Science in the metropolis: Vienna in transnational context, 1848-1918. Abingdon: Routledge 2020. 149-69.

945 PIŁATOWICZ J \& MAKSYMIUK K, The dissolution of the Society of Jesus and its influence on the development of mathematical and natural sciences education in the Principal School of the Realm in Cracow. PaedH 564 (2020) 447-62.

946 RUBÍ F C \& GÓMEZ S G, Natura et urbis in the socio-educational renovation of Barcelona City Council (1909-1933). HE 494 (2020) 476-97.

947 STIFTER C H, Science-orientated popular education: heterotopic learning venues for scientific knowledge in Vienna, 1887-1918. In ASH M G ed, Science in the metropolis: Vienna in transnational context, 1848-1918. Abingdon: Routledge 2020. 196-217. 
948 SVATEK P, Academic geography and its networks in Vienna and Berlin: a first comparative study. In ASH M G ed, Science in the metropolis: Vienna in transnational context, 1848-1918. Abingdon: Routledge 2020. 131-48.

949 VILHJÁLMSSON T, The boundaries of pleasure: the diary of Ólafur Daviðsson and the heterotopia of the nineteenth-century Reykjavík Latin School. SJH 455 (2020) 593-614.

\section{Emotions and the senses}

950 BARUA R, Matters of the heart: romance, courtship, and conjugality in contemporary Delhi. ILWCH 971 (2020) 109-33.

951 KENNY N, Saving the steamship: Brussels' Maison de la Radio and the urban emotions of a broadcasting institution. IJHerS 268 (2020) 806-22.

952 LE DEVEHAT M, The local perception of the memory of communism in a dictator's hometown: the case of Gjirokastra. IJHerS 268 (2020) 753-67.

953 RIISMANDEL K, Neighborhood of fear: the suburban crisis in American culture 1975-2001. Baltimore, MD: Johns Hopkins University Press 2020. pp 256.

954 RODÉHN C, Emotions in the Museum of Medicine. An investigation of how museum educators employ emotions and what these emotions do. IJHerS 262 (2020) 201-13.

955 WARREN M, 'When the Moon shall become as large as the Sun': unsettled settlers and the early Sydney press. HA 171 (2020) 115-33.

\section{$\mathrm{X}$ Attitudes towards cities}

\section{Attitudes towards cities}

956 ALLBESON T, Photography, reconstruction and the cultural history of the postwar European city. Abingdon: Routledge 2020. pp 290.

957 ANDERSON D, 'Its flames will blaze': the battle for Fallujah, 7-13 November 2004. In FREMONT-BARNES G ed, A history of modern urban operations. London: Palgrave Macmillan 2020. $321-44$.

958 ARNOLD J, 'That rather sinful city of London': the coal miner, the city and the country in the British cultural imagination, c. 1969-2014. UH 472 (2020) 292-310.

959 ARNOLD J, BECKER T \& SAUMAREZ SMITH O, The de-industrializing city in the UK and Germany: conceptual approaches and empirical findings in comparative perspective. UH 472 (2020) 194-8.

960 BEAN T, 'Come ye back to Mandalay': 14th Army's battle for Mandalay, March 1945. In FREMONTBARNES G ed, A history of modern urban operations. London: Palgrave Macmillan 2020. 129-49.

961 CARMINATI L, Port Said and Ismailia as desert marvels: delusion and frustration on the Isthmus of Suez, 1859-1869. JUH 463 (2020) 622-47.

962 CASSETTE M, My Omaha obsession: searching for the city. Lincoln, NE: University of Nebraska Press 2020. pp 400.

963 CHOTZAKOGLOU C G, Art and urban planning as identity and reflection of the great city: (Constantinople) and the sacred polis (Jerusalem) in the Byzantine provinces. In LOUKAKI A ed, Urban art and the city: creating, destroying, and reclaiming the sublime. Abingdon: Routledge 2020. 75-89.

964 DESMAREST C G \& MACKECHNIE A, 'An Edinburgh citizen of very ancient standing': Prime Minister Lord Rosebery, architectural patron and conservationist. BOEC 161 (2020) 19-46. 
965 EDWARDS A, 'Acting with restraint and courtesy, despite provocation?' Army operations in Belfast during the Northern Ireland 'Troubles', 1969-2007. In FREMONT-BARNES G ed, A history of modern urban operations. London: Palgrave Macmillan 2020. 287-319.

966 FOSKOLOU V, On real and imaginary cities: textual and visual representation of cities and the perception of urban space in the Byzantine world. In LOUKAKI A ed, Urban art and the city: creating, destroying, and reclaiming the sublime. Abingdon: Routledge 2020. 59-74.

967 FREITAG F, Popular New Orleans: the crescent city in periodicals, theme parks, and opera, 1875-2015. Abingdon: Routledge 2020. pp 356.

968 FRYSZTACKA C M, A discourse of modernity? Warsaw's press on urban poverty (1880s-1910s). In GANTNER E, HEIN-KIRCHER H \& HOCHADEL O eds, Interurban knowledge exchange in southern and eastern Europe, 1870-1950. Abingdon: Routledge 2020. 165-87.

969 GROSVENOR I, HERMAN F \& ROBERTS S, Cultivating children and youth: transnational explorations of the urban and the natural. HE 494 (2020) 435-9.

970 HAMETZ M, Remembering Sissi's escape: nostalgia marketing in the Mediterranean. In FOLIN M \& PORFYRIOU H eds, Controversial heritage and divided memories from the nineteenth through the twentieth centuries. Abingdon: Routledge 2020. 107-19.

971 HANNA E, Snapshot stories: visuality, photography, and the social history of Ireland, 1922-2000. Oxford: Oxford University Press 2020. pp 288.

972 HARMSEN P, Armageddon rehearsed: the battle of Shanghai, August-November 1937. In FREMONT-BARNES G ed, A history of modern urban operations. London: Palgrave Macmillan 2020. 33-54.

973 HERDMAN J M, The Prince and the Penny Chartist: the Great Exhibition in Reynold's Newspaper. VPR 533 (2020) 313-37.

974 JONES F L, 'Live nobly, die gloriously': the battle for Saigon - Tet 1968. In FREMONT-BARNES G ed, A history of modern urban operations. London: Palgrave Macmillan 2020. 253-86.

975 KORRES M, Ancient Greek cities as works of art. In LOUKAKI A ed, Urban art and the city: creating, destroying, and reclaiming the sublime. Abingdon: Routledge 2020. 24-38.

976 KRAIKOVSKI A, BOGACHEV N \& LOMAKINA I, Playing maritime capital: the Baltic Sea in the touristic representations of St. Petersburg. IJMH 324 (2020) 928-45.

977 LAMBKIN K J, Robin John Tillyard's 1936 Queensland excursion: uncivilised towns, unmitigated discomfort and fossil insects. ANH 471 (2020) 92-104.

978 L'OFFICIAL P, Urban legends: the South Bronx in representation and ruin. Cambridge MA: Harvard University Press 2020. pp 320.

979 LOUKAKI A, Assaulting the archetypes: urban materiality and the current adulation and hatred for marble in Athens. In LOUKAKI A ed, Urban art and the city: creating, destroying, and reclaiming the sublime. Abingdon: Routledge 2020. 39-58.

980 LOUKAKI A, Introduction: urban art between archetypal sublimity and ultramodern insurgency. In LOUKAKI A ed, Urban art and the city: creating, destroying, and reclaiming the sublime. Abingdon: Routledge 2020. 1-23.

981 MCCUTCHEON P, Rocking the casbah: 10 Parachute Division and the battle for Algiers - 1957. In FREMONT-BARNES G ed, A history of modern urban operations. London: Palgrave Macmillan 2020. 185218.

982 MANASSERO M A V, Genoa in the travel diaries of Jehan Lhermite (1587) and Cesare Magalotti (1625). In FOLIN M \& MUSARRA A eds, Cultures and practices of coexistence from the thirteenth through the seventeenth centuries. Abingdon: Routledge 2020. 237-51. 
983 MANN C, 'The rest of the day was perfectly bloody': the 51st Highland Division and town clearance in Germany, February-March 1945. In FREMONT-BARNES G ed, A history of modern urban operations. London: Palgrave Macmillan 2020. 103-28.

984 OCHONU M, Colonial itineraries: Muhammadu Dikko's metropolitan adventures. JAfrH 612 (2020) 179-200.

985 PALOU S \& CORREYERO B, Tourism advertising and propaganda during the postwar. The case of Barcelona. In PELLEJERO MARTÍNEZ C \& LUQUE ARANDA M eds, Inter and post-war tourism in western Europe, 1916-1960. London: Palgrave Macmillan 2020. 129-58.

986 RICHTER D, Mirrored imaginaries: urban chroniclers in Buenos Aires and Montevideo, 1910-1936. JUH 463 (2020) 541-60.

987 RIDGEN I, The poisoned chalice: urban warfare in the twenty-first century and beyond. In FREMONT-BARNES G ed, A history of modern urban operations. London: Palgrave Macmillan 2020. $345-61$.

988 RIES L A, 'The crusade against ugliness': J. Horace McFarland and photography. PH 871 (2020) 113-21.

989 RIGDEN I, The battle of Berlin, April-May 1945. In FREMONT-BARNES G ed, A history of modern urban operations. London: Palgrave Macmillan 2020. 151-83.

990 SHERER I, A bloody carnival? Charles V's soldiers and the sack of Rome in 1527. RS 345 (2020) 784-802.

991 SIDOLI E, PALUMBO M \& PARKIN S, A Florentine merchant's visit to Canterbury Cathedral in 1444. JMH 465 (2020) 572-95.

992 SMITH G, The Cascine in the eighteenth and early nineteenth centuries: a context for François-Xavier Fabre's view of Florence from the Cascine. SHGD 401 (2020) 65-79.

993 TAYLOR W A, Among the ashes of emperors: Operation Hue City - January 1968. In FREMONTBARNES G ed, A history of modern urban operations. London: Palgrave Macmillan 2020. 219-51.

994 TESSARI A, Verona and the myth of Romeo and Juliet: love affair or merely affairs. JTH 123 (2020) 298-316.

995 TOFFOLO S, Describing the city, describing the state: representations of Venice and the Venetian terraferma in the Renaissance. Leiden: Brill 2020. pp x +332 .

996 VANDEBURIE J, 'A dragon with nine heads': the changing reputation of Crusader Acre, c. 11911291. In FOLIN M \& MUSARRA A eds, Cultures and practices of coexistence from the thirteenth through the seventeenth centuries. Abingdon: Routledge 2020. 9-39.

997 VERMEULEN K, Conceptualizing biblical cities. London: Palgrave Macmillan 2020. pp x + 275 .

998 WALKER N R, Victorian visions of suburban utopia: abandoning Babylon. Oxford: Oxford University Press 2020. pp 576.

999 WALSH S, The battle of Stalingrad, September-November 1942. In FREMONT-BARNES G ed, $A$ history of modern urban operations. London: Palgrave Macmillan 2020. 55-101.

1000 WESTWOOD G, The rhetoric of the past in Demosthenes and Aeschines: oratory, history, and politics in classical Athens. Oxford: Oxford University Press 2020. pp 432.

\section{Views of the city in literature, graphics and drama}

1001 ALBANI J P, Between convention and reality: visual approaches to cities in post-Byzantine icon painting. In LOUKAKI A ed, Urban art and the city: creating, destroying, and reclaiming the sublime. Abingdon: Routledge 2020. 104-19. 
1002 AUVRAY G, Quelques observations sur les ruines du péplum. Entre histoire, symbole et stéréotype cinématographique. HU 581 (2020) 81-101.

1003 CHANCELLOR H, London, repentance, and early modern English literature, c. 1590-1600. LJ 453 (2020) 318-34.

1004 CORDES V F, New York in cinematic imagination: the agitated city. Abingdon: Routledge 2020. pp 254.

1005 COREY J T, Reimagining Harrisburg's Old Eighth Ward through poetry. PH 871 (2020) 192-202. 1006 DONAL BURKE T, From terror to terrorism in Bleak House: writing the event, representing the people. $L J 451$ (2020) 17-38.

1007 GODFREY A C, Active landscape photography: theoretical groundwork for landscape architecture. Abingdon: Routledge 2020. pp 192.

1008 HENTSCHELL R, St Paul's Cathedral precinct in early modern literature and culture. Oxford: Oxford University Press 2020. pp 288.

1009 POPESCU M-I \& JAHAMAH A, 'London is a city built on the wreckage of itself: state terrorism and resistance in Chris Cleave's Incendiary and Mohsin Hamid's Exit West. LJ 451 (2020) 123-45. 